\title{
Endogenous Financial Constraints and Innovation
}

\author{
December 2018
}

\section{Henry Lahr}

Centre for Business Research, University of Cambridge, Trumpington Street, Cambridge, CB2 1AG, and Department of Accounting and Finance, The Open University, The Open University Business School, Walton Hall, Milton Keynes, MK7 6AA, UK.

h.lahr@cbr.cam.ac.uk, +44 1908332648

\author{
Andrea Mina \\ Sant'Anna School of Advanced Studies, Piazza Martiri della Libertà, 33, 56127 Pisa, Italy and \\ Cambridge Judge Business School, University of Cambridge, Trumpington Street, Cambridge, CB2 \\ $1 \mathrm{AG}, \mathrm{UK}$, \\ andrea.mina@santannapisa.it,+39050883288
}

\begin{abstract}
We investigate which indicators of a firm's innovation activities are associated with financial constraints and analyse the nature and direction of causal links between innovation and financial constraints. By estimating simultaneous bivariate probit models on data from the UK Innovation Surveys, we show that among innovation inputs, R\&D activity increases the likelihood that firms face financial constraints while innovation outputs in the form of new-to-market products seem to generate financial constraints. Reverse effects on innovation appear limited to external R\&D.
\end{abstract}

Keywords: Innovation; Financial constraints; R\&D; Intangible investment

JEL classification: D92; E22; G32; O31; O32 


\section{Introduction}

Innovation is widely recognised as a fundamental driver of economic growth, but the pathways to innovation are complex and often hindered by the fundamentally uncertain nature of research and development processes and their market outcomes (Rosenberg, 1994). Access to capital can be a significant barrier to innovation because it reduces investments in its core inputs (e.g., R\&D) which in turn may result in fewer new products and lower growth rates relative to the optimal case of frictionless capital markets (Hall and Lerner, 2010). By inducing risk and informational asymmetries into the relation between firms and investors, innovation can restrict the availability of finance when internal funds are not sufficient to sponsor R\&D projects (Cosh et al., 2009). This problem acquired special relevance in the aftermath of the 2008 financial crisis, during which the more innovative firms (and young and small firms in particular) might have been hit especially hard by reduced availability or rising external cost of capital (OECD, 2009), a likely consequence of higher product market uncertainty and the stronger information asymmetries associated with it. However, Kahle and Stulz's (2013) study of a large sample of public U.S. firms during the postLehman period casts doubt on the link between a shock in the supply of credit and firms' capital expenditures.

Despite a number of studies on the cash flow sensitivity of R\&D investments (see, for example, Hall, 1992; Himmelberg and Petersen, 1994; Harhoff, 1998; Mulkay et al., 2000; Bond et al., 2005), the extent to and the way in which innovation activities of firms may exacerbate financial constraints are not sufficiently understood (Hall, 2010). The literature on financial constraints discusses the identification and nature of financial constraints (Fazzari et al., 1988, 2000; Kaplan and Zingales, 1997, 2000; Carpenter et al., 1998; Cleary, 1999; Cleary et al., 2007; Hadlock and Pierce, 2010; Farre-Mensa and Ljungqvist, 2016) but tends to neglect the study of their determinants, particularly in the innovation domain: financial constraints are typically difficult to observe, and this often prevents their use as an outcome variable. Increasing recognition of the multidimensional nature of innovation calls for analytical approaches that focus not only on the role 
of innovation inputs (e.g., R\&D) but also on the relationship between innovation outputs (e.g., new products or new production processes) and financial constraints. Some of these innovation outcomes have recently been related to financial constraints in cross-sectional studies (Hottenrott and Peters, 2012; Audretsch et al., 2014; Mancusi and Vezzulli, 2014; Lee et al., 2015). However, a comprehensive study of their relative importance of innovation inputs and outputs in determining and being determined by financial constraints is missing.

More importantly, the potential feedback loop between financial constraints and innovation must be taken into account. On the one hand, financial constraints can limit firms' engagement in risky R\&D activities (Hall and Lerner, 2010); on the other hand, innovation can generate financial constraints through associated asymmetric information caused by the high costs and uncertainties generated in lengthy processes of R\&D, testing, distribution and marketing (Scherer, 1999; Brown et al., 2009). The existing literature either assumes exogeneity of financial constraints or employs indirect procedures, such as Heckman-type corrections or regression discontinuity designs, to estimate the treatment effect of financial constraints on innovation (Acharya and $\mathrm{Xu}, 2016$ ). However, a modelling approach that directly addresses the fundamental endogeneity problem in the relationship between firm financing and innovation is preferable, as endogeneity can have serious implications for the validity of empirical findings and consequently for the lessons that can be drawn from this body of evidence to inform policy.

In this paper, we investigate the link between financial constraints and innovation through multivariate longitudinal analyses of direct measures of a firm's financial constraints and innovation characteristics. We model firms' innovation-financing behaviours comprehensively and simultaneously along different dimensions of innovation, including inputs, processes and outputs, and not simply R\&D. Our strategy is to treat financial constraints and innovation as a simultaneous dynamic system while accounting for unobserved firm-specific effects. We develop a set of simultaneous equations models, suited to the treatment of endogeneity, and apply them to UK Innovation Survey panel data available through the UK Office of National Statistics (ONS). These 
data contain a wealth of information on firm innovation activities that have not been used to date to address the problem of firm financing in a simultaneous setting. We also consider in our analysis small and non-listed firms. These are usually missing from studies of cash-flow sensitivities of investment, even though small and medium-size firms (SMEs) play a fundamental role in the dynamics of Schumpeterian creative destruction that characterise modern competitive processes (Schumpeter, 1942; Acs and Audretsch, 1990; Breschi et al., 2000; Aghion et al., 2013).

Our results suggest that innovating firms are more likely to experience financial constraints. By considering a broad range of innovation indicators, we show that only some innovation inputs and outputs increase the likelihood that firms experience financial constraints. We further show that innovation outputs in the form of products that are new to the market cause financial constraints. In line with theory, effects of innovation on financial constraints are strongest where informationally opaque activities and uncertain market outcomes create a potential for severe agency conflicts. The reverse effect of financial constraints on the likelihood of innovation appears limited to external $R \& D$ activity that is not captured by formal $R \& D$ spending. While the literature has traditionally emphasised that financial constraints may prevent firms from innovating, we stress that the resource requirements of firms increase when they innovate. This implies that from a policy viewpoint attention should be paid not only to the costs of technological search, but also to the capital outlays required by the exploitation of innovation, which are often underestimated.

Our study contributes to the literature on the effects of financial constraints on innovation (e.g., Canepa and Stoneman, 2007; Hoegl et al., 2008; D'Este et al., 2012; Iammarino et al., 2012; Hottenrott and Peters, 2012; Audretsch et al., 2014; Acharya and Xu, 2016; Howell, 2016; Pellegrino and Savona, 2017) and to the study of financial constraints more broadly (e.g., Fazzari et al., 1988, 2000; Hall, 1992; Himmelberg and Petersen, 1994; Kaplan and Zingales, 1997, 2000; Carpenter et al., 1998; Cleary, 1999; Bond et al., 2005; Cleary et al., 2007; Brown et al., 2009; Hadlock and Pierce, 2010; Brown et al., 2012; Lee et al., 2015; Farre-Mensa and Ljungqvist, 2016). First, we investigate the relative importance of a broad range of indicators of a firm's innovation 
profile as determinants of financial constraints, including measures of R\&D and the firm's innovation outcomes. Secondly, we employ a structural model to account for endogeneity in the relationship between financial constraints and innovation and are thus able to study the bivariate and dynamic interaction of both variables and to resolve previous conflicting evidence. Thirdly, we contribute to the literature on the identification of financial constraints based on survey data.

The paper is organised as follows. The next section reviews the relevant literature and frames our research design. Section 3 presents our data, models and estimation approach. Section 4 presents the results of our main analyses. Section 5 extends the results by showing alternative model configurations and estimation methods. It further discusses and tests the validity of our measure of financial constraints. In section 6 we draw the study to a close by reflecting on its contribution to the literature and by commenting on its policy implications.

\section{Financial constraints and investments in innovation}

We begin the literature review by discussing the problems of identification and evaluation of the drivers of financial constraints. We then reflect on the specific role of innovation and focus on the bidirectional relationship between innovation and financial constraints.

\subsection{Measurement and determinants of financial constraints}

Empirical studies of firms' financing behaviours reflect the existence of constraints on raising external finance (e.g., Fazzari et al., 1988, 2000; Whited, 1992; Bond and Meghir, 1994; Carpenter et al., 1998; Bond et al., 2003; Mulier et al., 2016). Authors typically measure the degree of financial constraint by screening a firm's financial reports for evidence of firms identifying themselves as financially constrained or by comparing the cash flow sensitivity of investment between subsamples constructed from a measure that proxies for constraints. Among the first of these studies, Kaplan and Zingales (1997) (KZ) examine the management's discussion of the firm's liquidity (i.e., future needs for funds and sources of liquidity, as well as demand for funds) and classify the firm into five categories according to the degree of financial constraint, using quantitative information to augment the qualitative data (e.g., information on dividends and share 
repurchases). Hadlock and Pierce (2010) expand the method of Kaplan and Zingales to include more firms, carefully rate statements in the firm's $10-\mathrm{K}$ that pertains to a firm's ability to raise funds or finance its operations and aggregate these ratings to arrive at a five-point scale similar to the one developed by Kaplan and Zingales. Hoberg and Maksimovic (2015) automate the reading process and machine-read the "Management's Discussion and Analysis" in 10-K text for all electronically filed 10-Ks from 1997 to 2009.

These measures of financial constraints can then be used as outcome variables to find determinants of financial constraints. Kaplan and Zingales (1997) estimate an ordered logit model using their classification and find that a firm's cash flow, market-book ratio, leverage, dividends and cash holdings explain whether a firm can be classified as financially constrained. These variables have themselves become a common proxy for financial constraints in the literature (the first ones to define the $\mathrm{KZ}$ index as a linear combination of regressors of constraints are Lamont, Polk and Saá-Requejo, 2001). Subsequent studies have found that cash flow, Q, leverage, dividends, cash, size and age explain constraints (Whited and Wu, 2006; Hadlock and Pierce, 2010). Hoberg and Maksimovic (2015) find that constraints are more severe for R\&D-intensive firms, supporting earlier findings by Brown, Fazzari and Petersen (2009).

If dynamic investment models of the firm (Bond and Meghir, 1994) are correct, the presence of financial constraints in firms that self-report or exhibit signs of being constrained can be confirmed by estimating the sensitivity of investment to changes in cash flow for subsamples of apriori constrained and unconstrained firms. Differences in the sensitivity to cash flow between these groups indicate that the variable used to split the sample (e.g., dividends, KZ index, Hadlock-Pierce index) reflects financial constraints. Historically, studies of firm's cash flow sensitivity of investment have mostly used investment in tangible assets to test for financing frictions. Models with R\&D investments rather than physical investment as an outcome variable were developed 
much later because of the limited availability of long R\&D time series and methodological difficulties such as those encountered in measuring the R\&D capital stock. ${ }^{1}$

The analytical framework of regressing investment on cash flow and average Q (approximating marginal Q) - including the very identification of financial constraint and financial distress - has, however, been challenged in subsequent studies on methodological and theoretical grounds (Schiantarelli, 1996; Kaplan and Zingales, 1997, 2000; Cleary, 1999; Cleary et al., 2007; Chen and Chen, 2012). The use of conventional regressions of investment on cash flow has been criticised for neglecting the potential endogeneity of cash flow and for not controlling for external financing (Brown and Petersen, 2009). Hu and Schiantarelli (1998) recognise the methodological limitation of pre-classifying firms into constrained and unconstrained subpopulations and then estimating cash flow sensitivities for each. They estimate instead a switching regression model in the traditional Q investment model framework. In line with early studies, this approach mostly confirms findings of financial constraints to investment (Almeida and Campello, 2007). Riddick and Whited (2009) argue that the positive correlation between investment and cash flow is better explained by a productivity shock that simultaneously affects cash flow and the marginal product of capital, inducing firms to invest in additional productive capacity. Most recently, Farre-Mensa and Ljungqvist (2016) called into question the ability of conventional measures of financial constraints to distinguish constrained from unconstrained firms. They use exogenous shocks to firm's demand for external finance and show that firms classified as constrained by five measures (dividends, credit ratings and indices developed by Kaplan and Zingales (1997), Hadlock and Pierce (2010) and Whited and $\mathrm{Wu}(2006))$ are equally or better able to adjust their leverage in response to changes in the local tax regime.

\footnotetext{
${ }^{1}$ For extensive discussions of this literature see the reviews by Schiantarelli (1996), Hubbard (1998), Bond and Van Reenen (2007) and Coad (2010). See Brown and Petersen (2009) for a comparison of cash flow sensitivities of physical investment and R\&D.
} 
In addition to these theoretical and methodological difficulties, the scope of potential determinants of financial frictions has largely been limited to readily available accounting information. However, a firm's financial statements do not always accurately capture its business activities to a degree that can easily be related to its ability to raise finance. For example, a firm's supply schedule of capital varies with its projects and is likely to depend on availability of collateral and information asymmetries caused by R\&D activities (Farre-Mensa and Ljungqvist, 2016). Proponents of the "wedge" model of financial constraints, which assumes a higher cost of capital for external than for internal finance, maintain that such a wedge can be due to the opaqueness of a firm's projects and private information that cannot easily be communicated to external parties (Myers and Majluf, 1984; Krasker, 1986; Brown et al., 2009, 2012). It can be argued that a firm's efforts to innovate, a main cause of financing constraints, has received relatively little attention, partly as a result of limited data availability, although there are hardly any activities within firms that create a greater potential for moral hazard and similar agency problems related to asymmetric information.

\subsection{Endogeneity and the multifaceted nature of innovation}

Another reason for the lack of conclusive evidence on firms' innovation characteristics in relation to their financing behaviour is the bidirectional causality between the two constructs. While innovation is likely to affect a firm's ability to raise finance, the availability of funding can also constrain its ability to carry out research and innovation projects. Existing studies address this fundamental methodological problem in various ways. A number of studies concerned with technical change exploit the deregulation of intrastate and interstate branch banking in the U.S. in the 1970s until the mid-1990s as a natural experiment that relaxes financing constraints. While increased competition among banks as a result of interstate banking deregulation in the 1980s increases the number and quality of patents (Amore et al., 2013; Chava et al., 2013), increased market power of banks due to intrastate deregulation seems to reduce patenting (Chava et al., 2013). Banking deregulation mainly benefits private firms, which previously had limited access to credit 
from local banks (Cornaggia et al., 2015). Within the cash flow sensitivity framework, there also is some evidence of binding financial constraints for R\&D investment, which nonetheless appear to vary considerably across time periods and countries (Hall, 1992; Himmelberg and Petersen, 1994; Harhoff, 1998; Mulkay et al., 2000; Bond et al., 2005; Cincera and Ravet, 2010; Brown et al., 2012), often not unlike physical investment (Carpenter et al., 1998).

In addition to the problem of endogeneity of financial constraints as a determinant of innovation, this stream of contributions has a narrow focus on traditional indicators of innovation (predominantly audited R\&D expenditures and to a lesser extent patents). Following Schumpeter (1934), several authors have instead highlighted that innovation processes are multi-dimensional (see, for example, Kline and Rosenberg, 1986; Dosi, 1988; Crépon et al., 1998; Jaffe and Trajtenberg, 2002). Innovation inputs (e.g., R\&D, associated with the highest level of investment risk and information asymmetries) can be distinguished from intermediate outputs (e.g., inventions measured by patents) as well as from final outputs (innovated products, processes and services, which may be new to the firm or new the market). Moreover, each of these dimensions can be significantly affected by a range of practices and strategic choices about the sourcing of external knowledge, the acquisition of technologies and access to other complementary assets (Stoneman, 2001; Teece, 1992; 2010). The use of a broader and more precise range of innovation indicators has great potential to refine our understanding of firms' financing behaviours (Canepa and Stoneman, 2007).

We expect innovation characteristics of a firm that are related to intangible assets and uncertain market prospects to affect its perceived financing constraints to a greater extent than investment in externally observable and examinable new products and services with a well-known market. Expenses for research and development and advertising, which can be seen as proxies for asset intangibility, shape a firm's capital structure and are associated with smaller degrees of leverage (Bah and Dumontier, 2001; Carpenter and Petersen, 2002; Kayo and Kimura, 2011). The large information asymmetries and agency costs associated with new product development - 
especially in the high-tech industry - require complex and thus costly financing solutions, which often involve equity in the form of venture capital (Gompers, 1995). Czarnitzki and Hottenrott (2011) report evidence that cutting-edge R\&D projects may cause credit constraints more often than routine $R \& D$ investments. Lee et al. (2015) find that new-to-the-market innovations make it more difficult to access external capital. We thus expect that innovation activities and investment in early product development and opaque internal $R \& D$ projects will more likely generate financing difficulties than innovation outcomes such as new products in established markets or new business processes.

The introduction and continued implementation of Community Innovation Surveys (CIS) in Europe has enabled the measurement of different stages and dimensions of innovations on a large scale. The CIS also contains two specific questions on firms' perceived financial constraints (namely the extent to which 'access to finance' and 'cost of finance' constitute barriers to innovation). Systematic research into the links between environmental constraints and the inputs, processes and outputs of innovation has only begun relatively recently (Canepa and Stoneman, 2007; Savignac, 2008; Mohnen et al., 2008; Müller and Zimmermann, 2009; D'Este et al., 2012; Hottenrott and Peters, 2012; Audretsch et al., 2014; Acharya and Xu, 2016). ${ }^{2}$

Despite the quality of these contributions, there are considerable margins for progress on theoretical, methodological and empirical grounds. For example, the predominantly cross-sectional nature of the innovation output data used in the literature does not capture dynamic effects and state dependence in innovation activities. It also makes it difficult to identify the potential reverse causality between financial constraints and innovation. Prior art on this topic typically models either constraints or innovation as exogenous or introduces simultaneity by adding contemporaneous error correlation without allowing for two-way causality. One rare exception is a study of French firms

\footnotetext{
${ }^{2}$ Czarnitzki and Hottenrott (2011) analyse panel data on German firms that include different indicators inputs (research vs. development), but exclude indicators of innovative output. Interestingly, different R\&D indictors produce different effects on financial constraints.
} 
by Hajivassiliou and Savignac (2016), who use bivariate probit modelling with state dependency in both financial constraints and innovation variables. This analysis is limited by the use of only two CIS waves, but the findings suggest the possibility that innovation outcomes increase financial constraints, while financial constraints may reduce the likelihood of innovation. Hottenrott and Peters (2012) instead exploit a speculative question only contained in one wave of the Mannheim Innovation Panel to explore the determinants of financial constraints. Results obtained from crosssectional estimations suggest that financial constraints do not depend solely on the availability of internal finance but can be driven by the increased financial needs of innovating firms. Even though external investors might be able to observe the successful outcome of firms' R\&D investments, the effect of greater resources requirements or of market uncertainty appear to outweigh the reduction of information asymmetries. These insights deserve further investigation in a broader longitudinal setting that fully accounts for dynamic effects and reverse causality.

\section{Data and methodology}

\subsection{Data}

The Community Innovation Surveys (CIS) provide a rich direct source of information on firms' innovation activities and the economic environment in which these take place. In the UK, the data are collected at enterprise level by the Office of National Statistics. The CIS-UK 2011 sampled over 28,000 UK enterprises. ${ }^{3}$ The sampling frame included all enterprises with 10 or more employees in sections C-K of the Standard Industrial Classification (SIC) 2003 or 2007 in the official business register, which include both manufacturing and service sectors. The underlying sample is stratified by region, industry sector and size, and weights are attached to responses according to the firm's weight relative to the number of firms in the stratum. For all enterprises with 250 or more

\footnotetext{
${ }^{3}$ Department for Business, Innovation and Skills, Office for National Statistics and Northern Ireland. Department of Enterprise, Trade and Investment, UK Innovation Survey, 1994-2010: Secure Data Service Access [computer file]. 2nd Edition. Colchester, Essex: UK Data Archive [distributor], October 2012. SN: 6699, Available at http://dx.doi.org/10.5255/UKDA-SN-6699-2
} 
employees, a census was used. Small and medium sized enterprises were sampled at random within each stratum.

We use four CIS-UK waves (CIS4 to CIS7, covering the periods 2002-2004, 2004-2006, 2006-2008 and 2008-2010) to assess British firms' perceived constraints in accessing capital markets and their impact on innovation input and output. Later waves cannot be used for our purpose because, unfortunately, the questionnaire was changed for the period 2010-2012, which broke the continuity of our dependent variables. Individual cross sections contain about 15,000 observations each. After linking all four waves and excluding firms with incomplete time series (gaps) in all dependent variables, we obtain an unbalanced panel dataset with 3,218 firms. Due to missing variables in some dependent variables, some of our analyses may have slightly fewer firms. For independent variables, there are 2,659 two-period panels (2,628 for CIS5-6 and 31 for CIS 6-7) and 559 three-period panels, which yields 6,995 firm-year observations in total for our bivariate models. Because lagged dependent variables consume on observation per firm, dependent variables in our bivariate models have up to $6,995+3,218=10,213$ observations. Single-variable models have slightly more observations because observations for which the second dependent variable in our bivariate model would be missing remain in the sample. We match the CIS dataset with the Business Structure Database ${ }^{4}$ (BSD) to obtain additional variables on firm age and legal form, as well as for our analysis of firm death.

One feature of the data that needs special attention is a one-year overlap between consecutive surveys: each survey asks firms every two years about their activities over the previous three years. The potential serial correlation induced in the variables that are affected by this overlap has at least three implications for our modelling strategy. First, we use a dynamic model structure with lagged dependent variables to formally capture autocorrelation. Second, we choose lagged independent

\footnotetext{
${ }^{4}$ Office for National Statistics, Business Structure Database, 1997-2011: Secure Data Service Access [computer file]. 3rd Edition. Colchester, Essex: UK Data Archive [distributor], October 2012. SN: 6697, Available at http://dx.doi.org/10.5255/UKDA-SN-6697-3
} 
variables to construct economically meaningful models. Third, we test the robustness of our findings by incorporating a number of alternative measures of innovation inputs and outputs: the survey question about R\&D activities refers to a three-year period, whereas a similar question about R\&D expenditures asks for the firm's expenditures only in the last year of the survey period and is thus unaffected by overlapping observation periods. ${ }^{5}$

[Table 1 about here]

The distribution of firms in our sample is roughly comparable to the overall distribution of firms with 10 or more employees in the UK. We use SIC 2003 top-level classifications to construct industry dummy variables, which are presented in Table 1 . To add a finer level of detail to our study of R\&D and innovation activities, we split the manufacturing sector into high-tech and low-tech firms according to the OECD (2005) Science, Technology and Industry Scoreboard. Along the same line of reasoning, we separate R\&D service firms from "other services". Manufacturing firms are overrepresented compared to the UK population of firms with more than 9 employees $(32.7 \%$ vs $19.3 \%)$ at the expense of other sectors, most notably hotels and restaurants ( $5.5 \%$ vs $12.5 \%)$, trade (17.7\% vs $23.0 \%)$ and construction $(7.6 \%$ vs $11.2 \%)$.

\subsection{Variables}

Because we aim to simultaneously predict the presence of innovation activities and financial constraints in firms, all our dependent variables are binary indicator variables based on firms' selfreported measures of financial constraints and innovation. This choice of variables is further motivated by the observation that many firms report no R\&D expenditures but say they engage in

\footnotetext{
${ }^{5}$ The respondents' tendency to answer survey questions with the most recent year in mind (Tversky and Kahneman, 1973 ) is likely to help mitigate correlations across time periods. The availability heuristic will favour data that are more readily available in the respondent's memory and will underweight earlier years, thus attenuating possible autocorrelation effects that are not due to underlying economic processes but to survey design.
} 
$R \& D$ activities. There is evidence that firms do not report $R \& D$ expenses in their financial statements but still file patents (Koh and Reeb, 2015) or achieve product innovations (Santamaría et al., 2009). The reporting of $R \& D$ activities, if not the decision processes within firms, may follow a two-step process, in which firms first decide whether to engage in R\&D (i.e., a binary decision) and then decide whether and how much audited R\&D expenditures to report. For all our dependent variables on financial constraints and innovation, we either use survey items directly or construct binary variables from them.

Our six binary measures for R\&D activities are based on two survey questions. First, the questionnaire asks firms, "During the 3 year period [survey period, e.g. 2006-2008], did this business invest in any of the following, for the purposes of current or future innovation?" with answers "Internal Research and Development" and "Acquisition of external Research and Development," which translate into our dependent variables "R\&D internal (activity)" and "R\&D external (activity)." The binary variable "R\&D any (activity)" equals one whenever any of these two variables is answered positively by the firm. The second question is, "for each of the main innovation related investments in question [previous question], please ESTIMATE the amount of expenditure for the year [last year of survey period, e.g. 2008]." We treat positive amounts as indicators for internal and external $R \& D$ expenditures, which yields our dependent variables " $R \& D$ internal (expenditure)," "R\&D external (expenditure)," and "R\&D any (expenditure)."

Dependent variables for innovation outputs correspond to survey items for the development of new goods, services or processes. The questionnaire asks, "During the 3 year period [survey period], did this business introduce a. new or significantly improved goods? [...] b. new or significantly improved services?" and "did this business introduce any new or significantly improved processes for producing or supplying goods or services?” Additionally, we distinguish new goods and services that are new to the market from those that have been introduced by a competitor and are merely new to the firm. Finally, the variable "Innovation (any)" measures whether the firm introduced any type of innovation - good, service, or process. 
To assess financial constraints, firms answer the question, "how important were the following factors in constraining innovation activities: [...] availability of finance." "Cost of finance" was another possible constraint in this block of items. We focus on the availability of finance, however, to stay close to the meaning of financial constraints as an unobserved differential between internal and external cost of finance that limits the availability of external finance. One important advantage of using a self-response measure over cash-flow sensitivities is that we can directly observe changes over time. In other words, instead of searching for latent financial constraints in different groups of firms, we can directly investigate their determinants and impact on innovation. Whenever firms answer this item with "high" or "medium," we code this answer as "experiencing financial constraints" and treat the firm as unconstrained if the answer is "low" or "not experienced." About one quarter of the sample's firms report financial constraints, a proportion that is largely driven by the two CIS waves in 2008 and 2010, as one might expect from the general economic climate at the time. An econometric advantage of the UK Innovation Survey relative to the innovation surveys of other European countries is that all sample firms were asked whether they experienced financial constraints rather than only those that report innovation activities. We find a substantial proportion of firms in all innovation and constraint regimes, including financially constrained non-innovating firms. Potential selection biases within our sample are therefore greatly reduced.

Independent variables in our analyses relate to a firms' innovative capacity and the likelihood of financial constraints. The range of variables is limited by their availability in official - and linkable - ONS datasets. We measure a firm's size as the natural logarithm of its turnover in the last year of each survey period. Firm age is calculated as (2010 - birth year), where birth year is obtained from the BSD dataset and thus does not vary over time. Since age changes in much the same way for all firms over time, the likelihood of detecting a time series effect in addition to the cross-sectional one is quite small given the short panel. However, treating age as firm-year specific would introduce four additional parameters (Wooldridge terms, see Wooldridge, 2005), which remain insignificant in our tests. Whether a firm is a member of a group, is a subsidiary of a foreign 
firm and whether it has the legal status "company" can proxy for the availability of external finance and the availability of information about the firm to investors. Similarly, the market scope of a firm can be related to information production, but also to competitiveness in the market and the constant need to be ahead of the competition by innovating. Human capital is expected to have a positive impact not only on the likelihood to innovate, but also on the likelihood of financial constraints due to information asymmetries in firms with substantial intangible assets.

We augment this set of explanatory variables by adding the firm's market share to the R\&D and innovation equations and the gross profit margin as a regressor for financial constraints, such that each variable appears in only one of the two equations of our model. Market share has long been hypothesised to affect firm innovation activities (Scherer, 1967; Blundell, Griffith and Van Reenen, 1999; Aghion et al., 2005; Cohen, 2010). A firm's gross operating margin is correlated with cash flow and hence with financial constraints (as discussed in section 0) but not directly related to the firm's innovation output unless very long lags are considered (Geroski, Machin and Van Reenen, 1993). ${ }^{6}$ These exclusion restrictions improve the identification of the coefficients of interest, since identification would otherwise rely only on the model's functional form (one exclusion restriction would be sufficient in our model design to remove the reliance on the form of the likelihood function).

\subsection{Model specification and estimation}

We model the interaction between financing constraints and innovation as two simultaneous dynamic equations with concurrent error correlation between equations. This design formally captures the mutual endogeneity of financial constraints and innovation in a structural model that does not prioritise one or the other variable. It also makes it possible to cleanly accommodate two endogenous binary dependent variables in a regression framework.

\footnotetext{
${ }^{6}$ These are also the results obtained from cross-sectional models estimated on our sample (available upon request).
} 
The UK Innovation Survey's structure enables us to specify a dynamic panel structure, combining several past waves to form a proper panel $(\mathrm{T}>2) .{ }^{7}$ Linking four survey waves allows us, in addition to incorporating first-order dynamics, to use Wooldridge's (2005) approach to address the initial conditions problem in dynamic panels. This modelling approach, in combination with the panel dataset, has the advantage that we can directly address the effects of unobserved firm characteristics. As a result, we can model the entire population of firms regardless of their ex-ante innovation characteristics, such as being a potential innovator, rather than having to exclude noninnovators from the sample that may otherwise induce a spurious positive correlation between innovation and financial constraints that can be observed in cross-sectional studies (Pellegrino and Savona, 2017; Mancusi and Vezzulli, 2014; Savignac, 2008).

The system of equations for observed innovation activities $\left(y_{i t}^{A}\right)$ and financial constraints $\left(y_{i t}^{B}\right)$ is

$$
\begin{aligned}
& y_{i t}^{A}=I\left(X_{i t}^{A} \beta^{A}+\lambda_{A}^{A} y_{i, t-1}^{A}+\lambda_{B}^{A} y_{i, t-1}^{B}+c_{i}^{A}+\sigma_{i t}^{A}>0\right) \\
& y_{i t}^{B}=I\left(X_{i t}^{B} \beta^{B}+\lambda_{B}^{B} y_{i, t-1}^{B}+\lambda_{A}^{B} y_{i, t-1}^{B}+c_{i}^{B}+\sigma_{i t}^{B}>0\right),
\end{aligned}
$$

where

$$
\left(\begin{array}{l}
\sigma_{i t}^{A} \\
\sigma_{i t}^{B}
\end{array}\right) \sim N\left[\mathbf{0},\left(\begin{array}{cc}
1 & \rho_{i t} \\
\rho_{i t} & 1
\end{array}\right)\right]
$$

and $I(\cdot)$ is the indicator function. Exogenous variables $X_{i t}^{A}$ and $X_{i t}^{B}$ could have the same content, since the model would be identified by the assumption that errors are normally distributed. However, we impose exclusion restrictions on both equations to improve identification, using the firm's market share in the first equation that explains innovation activities and the gross operating margin in the financial constraints equation. Coefficients can only be identified up to scale, since

\footnotetext{
${ }^{7}$ Prior studies often lose observations in their attempts to incorporate lagged dependent variables by merging several cross-sections and therefore have to restrict the scope of their analysis to cross-sections (Silva and Carreira, 2012; Hajivassiliou and Savignac, 2016).
} 
error variances need to be normalised to unity as in univariate probit models. Analogous to Wooldridge's (2005) panel probit estimator, we add random effects conditional on exogenous variables and initial values of both dependent variables.

These random effects can be written as

$$
\begin{aligned}
& c_{i}^{A}=\alpha_{0}^{A}+\alpha_{1 A}^{A} y_{i 0}^{A}+\alpha_{1 B}^{A} y_{i 0}^{B}+\mathbf{x}_{i}^{A} \boldsymbol{\alpha}_{2}^{A}+a_{i}^{A} \\
& c_{i}^{B}=\alpha_{0}^{B}+\alpha_{1 A}^{B} y_{i 0}^{A}+\alpha_{1 B}^{B} y_{i 0}^{B}+\mathbf{x}_{i}^{B} \boldsymbol{\alpha}_{2}^{B}+a_{i}^{B},
\end{aligned}
$$

where the row vectors $\mathbf{x}_{i}^{A}$ and $\mathbf{x}_{i}^{B}$ contain past, present and future observations for exogenous variables, as well as time-constant variables. This implies that the effects of constant firm-specific variables cannot be separately identified, because they would appear in the model both as a main effect and in the conditional mean of the random effects. Random effects are assumed to be independent from the idiosyncratic firm-year error component in equation (1). Their unobserved components are modelled as

$$
\left(\begin{array}{c}
a_{i}^{A} \\
a_{i}^{B}
\end{array}\right) \sim N\left[\mathbf{0},\left(\begin{array}{cc}
\sigma_{a^{A}}^{2} & \sigma_{a^{A}, a^{B}} \\
\sigma_{a^{A}, a^{B}} & \sigma_{a^{B}}^{2}
\end{array}\right)\right] .
$$

Since the likelihood function for both equations is analytically intractable, we use a maximum simulated likelihood (MSL) method to estimate this system of equations. ${ }^{8}$ The error terms in all estimations are derived from 100 random draws. We tested smaller and larger sets of random errors and found that the added precision in larger samples is tiny compared to the increased computational costs of estimation, which are of the order of several hours per estimation. Standard errors shown in our results are based on the outer product of the gradient (OPG) method.

\footnotetext{
${ }^{8}$ Gouriéroux and Monfort (1996) and Train (2009) provide descriptions of estimation techniques and applications.
} 


\section{Results}

If we want to identify the dynamic effect of financial constraints on innovation and the reverse effect, we need to observe firms that switch from being constrained to unconstrained and from innovation-active to inactive or in the opposite direction. Table 2 shows the pattern of state transitions we observe in the data. A large number of firms remain inactive and unconstrained ("no/no" in the upper left corner in both panels). A plausible island of stability can also be identified for financially unconstrained R\&D performers and innovators (i.e., the "Yes/No" cell). As expected, the most unusual state transitions are firms that are financially constrained but start performing $\mathrm{R} \& \mathrm{D}$ in the next period $(1.4 \%+1.2 \%=2.6 \%)$. However, there are also relatively few firms that perform $R \& D$ in one period and who are constrained and stop their $R \& D$ efforts in the next period $(1.6 \%+1.2 \%=2.8 \%)$. Many firms switch between the constrained and unconstrained states or remain constrained while not performing $R \& D$ or innovating. R\&D and innovation show similar transition probabilities. About $12.9 \%$ of all firm-year transitions are from not performing R\&D to performing, while $12.4 \%$ switch from non-innovating to innovating. When we look at the opposite direction, $11.8 \%$ of $R \& D$ performers stop investing in $R \& D$, while $14.5 \%$ of innovators stop innovating. Similar magnitudes can be observed for financial constraints, where $15.1 \%$ of firmyear transitions switch into the constrained state, but only $11.5 \%$ become unconstrained. This finding mirrors the economic climate during the sample period, in which credit became more difficult to obtain. Since all cells are occupied by a considerable number of firms, we are confident that a simultaneous bivariate binary model can produce meaningful results.

[Table 2 about here]

\subsection{R\&D models}

Results from the estimation of simultaneous equation models with $R \& D$ and financial constraints (Table 3) reveal high persistence in both indicators over time. Financial constraints do not affect 
R\&D with the sole exception of a negative effect in our model for external R\&D activities. The coefficient for external R\&D expenditures has the next largest magnitude among R\&D models but is insignificant. This finding suggests that external $R \& D$ is more sensitive to changes in the availability of finance than internal R\&D. It is also plausible from the firm's point of view to reduce risky external procurement of $R \& D$ when resources become scarce in favour of more informationally transparent and vital internal R\&D. Firms have been found to smooth their R\&D expenditures by varying their cash holdings (Brown and Petersen, 2011), which explains the limited effect of financial constraints on $R \& D$ in our sample. Because internal $R \& D$ investments have large adjustment costs (Himmelberg and Petersen, 1994; Hall, 2002), as they tend to involve long-term investment in human capital or specialised equipment that cannot easily be sold, external R\&D contracts may be easier to terminate in the event of a liquidity shock. The long-term nature and cost-smoothing of most R\&D projects also explains the seeming disparity between firms' positive answer to the survey question on financial constraints (i.e., they admit that financial constraints are important in constraining their innovation activities) and our finding that there is no relationship with most R\&D variables: firms feel constrained in their activities, but they do not stop them altogether. They may, however, curtail expenses for non-vital projects, which tend to be external research projects more often than internal ones.

[Table 3 about here]

In line with earlier cross-sectional findings of increased financial constraints in technology firms with high R\&D expenditures (Westhead and Storey, 1997), R\&D increases financial constraints, but only in models using indicators of R\&D activity (Models 2 and 6), as opposed to R\&D expenditures (Models 1, 3 and 5). This suggests that firms engaging in informal R\&D activities have greater difficulties in attracting external finance relative to firms that engage in formal R\&D that is recorded in financial accounts and thus more readily observable by investors 
than unreported activities. From a theoretical viewpoint, this result supports the interpretation on innovation variables as measuring the potential for asymmetric information in a firm's innovation activities because informal $R \& D$ activities may be even harder for external investors to evaluate than those reported in audited financial statements.

There are no regular and systematically strong effects across $R \& D$ indicators for other timevarying variables. In two instances (Models 2 and 6), turnover seems to exert a negative effect on the likelihood of a subsequent internal R\&D activity - a possible sign that growing firms slow down $R \& D$ in the following survey period. Interestingly, time effects in the R\&D equations reflect external macroeconomic conditions. Firms report R\&D activities more frequently for CIS6 (2006-2008) relative to CIS5 (2004-2006), while engagement in R\&D deteriorates significantly during the financial crisis (CIS7 in 2008-2010). This can be explained in the light of the adverse climate in product markets characterizing the last years of our sample period compared to the relatively more favourable climate of 2006 and the best part of 2007. Market demand fluctuations are a more appropriate explanation of these effects relative to the financial environment because we already control for the firms' financing conditions. Foreign ownership is negatively associated with R\&D in four (Models 1, 2, 5, 6) out of six models, which implies that R\&D investments may be overall closer to the firms' overseas headquarters. ${ }^{9}$ Finally, time-varying market share is only positive and weakly significant in one model, which mirrors the diverse theoretical predictions on

\footnotetext{
${ }^{9}$ It is important to note that the presence of $x_{i}$ in equation (3) prevents us from identifying time-constant variables, because we cannot separate the effect of these variables on both outcome variables from their correlation with the random effects in equation (3). For example, firms owned by a foreign parent seem to perform less internal R\&D. Because the indicator for UK subsidiaries of foreign firms would also enter the conditional distribution of the random effects, including this variable in $X_{i t}$ would cause perfect collinearity with the one in $x_{i}$. Hence, instead of foreign ownership directly causing less R\&D, it might be related to some unobserved quality which in turn is associated with less R\&D without any implication of causality. It might even be the case that less research-intensive businesses are acquired by foreign firms more often.
} 
the effect of market structure on innovation (Cohen, 2010), although we note that market share as a Wooldridge term positively predicts $\mathrm{R} \& \mathrm{D}$ in most models, as well as in single-variable regressions (see section 5.1).

Among the determinants of firm financial constraints, besides the role of $R \& D$, results show negative and significant effects for human capital, operating margin and age - that is, these firm characteristics mitigate financial constraints. The effect of firm age is to be expected because information about older firms is more readily available than for younger firms, thus reducing information asymmetries and consequently the cost of external relative to internal capital. ${ }^{10}$ Firms with higher operating margins tend to have more free cash flow, while belonging to a group may enable firms to access an internal capital market, both of which reduces their dependency on external finance. The apparent negative effect of human capital is instead more difficult to interpret: intangible assets, such as human capital, should in theory aggravate information asymmetries in the market for external capital, and prior cross-sectional evidence points toward an increased likelihood of financial constraints for firms with a high level of human capital (Hottenrott and Peters, 2012). On the one hand, variations in human capital over time seem unable to explain the likelihood of observing R\&D. On the other hand, human capital is positively related to R\&D through unobserved firm effects (Wooldridge terms in the R\&D equation), which explains why we do not find a positive effect for time-varying human capital. Turning to the relationship between human capital and financial constraints, we find that firms with a larger share of employees with a degree are more likely to face financial constraints, but only through unobservable firm characteristics related to human capital. Over time, instead, human capital mitigates financial constraints. A negative effect can be explained if we assume that increasing human capital can lead to higher productivity, which in turn - ceteris paribus - should be associated with growth and therefore more favourable financial prospects. It is also possible that after controlling for the adverse effect of R\&D on constraints,

\footnotetext{
${ }^{10}$ This result must however be interpreted with caution since age is constant across time periods and might also be correlated with unobserved random effects that reduce financial constraints.
} 
human capital, as measured by the ratio of staff with a degree, exerts a residual beneficial effect by helping to overcome information gaps between the firm and potential investors.

\subsection{Innovation models}

The results generated by models with innovation measures (Table 4) reveal that not only R\&D but also innovation is highly persistent through time and across indicators. The introduction of new goods, new services and new processes as well as products that are new to the firm or new to the market is strongly related to past success at innovating.

Financial constraints do not appear to affect the likelihood of innovating. Coefficients for all types of innovation are far from being significant. As is the case in R\&D models, this finding suggests that firms do not abandon their innovation programs in response to potentially short-lived difficulties in raising finance. Among the variables that exert a significant effect on innovation, market scope has a positive effect, which suggests that operations on a larger market favour innovation, and in particular new-to-market innovation. Being part of a group seems instead to impede service innovation (Model 6), a possible sign that service innovation is highly concentrated within few units in large service firms or that being part of a group constrains firms' interaction with final users and their ability to change the process of service delivery. Finally, firms seem to have been relatively more innovative during the period 2006-2010. Both time effects are positive for new-to-market innovations (Models 1 and 2). This could indicate an effect of the time lag between R\&D and innovation: adverse financial market conditions affect the firms' financial situation immediately, as reflected in time effects, but have a delayed impact on R\&D investment, which in turn is translated into innovation with a time lag. ${ }^{11}$

[Table 4 about here]

\footnotetext{
${ }^{11}$ An alternative explanation is that firms had to introduce new products to adapt to changes in demand.
} 
While financial constraints do not affect innovation, inspection of the results for the financial constraints equation in Table 4 reveals that some types of innovation aggravate financial constraints. We find positive coefficients for new-to-market innovation (Model 2) - in line with Hottenrott and Peters' (2012) cross-sectional evidence - and for new processes (Model 5). All coefficients for innovations are positive with the exception of new products that are only new to firm, which suggests that only the introduction of tried and tested products may be welcomed by external investors. From an agency perspective, this makes sense: it seems unlikely that new products and services, which are readily available for inspection by investors, should introduce asymmetries in financing relations that could lead to financial constraints.

These findings can be interpreted as an indication of financing needs not met by external sources of capital. It is indeed interesting to see that the indicators of innovation that affect financial constraints correspond to the riskiest and most capital-intensive innovations: new-to-market innovations. This is compatible with the view that financial pressures increase in firms facing the costs associated with the scaling-up of production, the expansion of logistics operations and the early market diffusion of their new products. It is also possible that given the high variability in the quality of innovations, financial pressures increase because the market does not always respond positively to the introduction of new products. It is important to stress, however, that models in Table 4 employ innovation outputs as indicators for general innovative activities and thus might capture aspects of informationally opaque $R \& D$ projects that cause financial constraints. From an investor's point of view, innovation-by-imitation (innovation new only to the firm) should be more transparent than less readily inspected types of innovations. The interpretation that R\&D projects feed into new products which are then correlated with financial constraints is also compatible with our results.

\subsection{Unobserved heterogeneity in $R \& D$ and innovation}

The inclusion of cross-sectional variables in our specifications of random effects provides some estimation benefits and offers insights into unobserved firm characteristics. Controlling for initial 
conditions through Wooldridge (2005) terms in both equations contributes to the identification of sensible and stable coefficients but reduces many significant coefficients found in univariate models (see Tables 6 and 7 in section 5.1). Our modelling strategy thus reduces the likelihood of spurious results that are due to unobserved heterogeneity. For example, initial conditions of R\&D, innovation and financial constraints (i.e., in CIS4, corresponding to the first two lines under Wooldridge terms in Tables 3 and 4), which enter the conditional distribution of random effects in equation (3), turn out to be highly significant and positive in the R\&D and financial constraints equations. This finding also suggests that future research might benefit from investigating the unobservables that link a firm's financial environment and its innovation capabilities.

The inclusion of initial states for both outcomes in both equations, while retaining first-order dynamics, offers further insights into unobservable firm characteristics. Consider the positive coefficients for initial R\&D conditions ("R\&D in CIS4") in the financial constraints equation in Table 3. Initial R\&D activities are positively correlated with unobservables related to financial constraints, whereas time-varying $R \& D$ itself ("R\&D (lag)") is significant but only in two models. This suggests that being R\&D active - interpreted as a firm effect - could lead to financial constraints, whereas observed year-on-year changes in R\&D status are less important for financial constraints. Nothing may have changed in the underlying characteristics of the firm, although it temporarily does not show any R\&D activities. Capital market participants may thus be able to distinguish $R \& D$ performers, including those in a latent $R \& D$-performing state without visible activities, from non-performers.

Similarly, success at innovating as a firm effect does not affect financial constraints ("Innovation in CIS4" in the financial constraints equation in Table 4), as would be expected under standard agency theory, because innovation in itself does not cause information asymmetries. Another interpretation is that there is no such thing as a latent innovation state, that is, there is no firm effect for innovation that adds to the overall firm random effect in the financial constraints equation. Innovations might be entirely random conditional on our observed variables. These 
interpretations are available under the normal interpretation of the financial constraints variable, that is to say a differential between external and internal financing costs and therefore a shortage of external funds. New-to-market innovations increase financial constraints, because these are more fundamental innovations that carry a greater risk of information asymmetries. In addition to this conventional explanation, we can interpret the survey question on constraints in more general terms as a signal of the demand for finance that usually follows successful innovations. Firms introducing novel products may find it necessary to approach external capital markets for expansion financing (ramping up production and marketing). This increase in the demand for finance, if unmet, produces a higher likelihood of financial constraints as detected in the Innovation Survey data.

Overall, innovation success in the previous period is more important for future innovation success than past $R \& D$ is for future $R \& D$ when compared to the importance of initial conditions. In other words, coefficients for lagged innovation are about as large as coefficients for initial innovation conditions ("Innovation at CIS4"), while initial R\&D conditions have a much stronger effect on future $R \& D$ activities than lagged $R \& D$. This again suggests that there are unobserved firm characteristics that predispose firms to constantly perform R\&D. Innovation, on the other hand, depends less on constant firm characteristics, but rather on past success in innovating. In general, the link between innovation outcomes and financial constraints appears weaker than the one between R\&D and financial constraints. Although both indicators for inputs or outputs in the innovation process explain financial constraints, the relationship through cross-equation correlation and random effects is considerably weaker. Initial conditions of innovation and financial constraints in one equation are not significant in the other in Table $4 .{ }^{12}$ Hence, unobserved firm heterogeneity in one variable seems to be unrelated to the other. The substantial correlation in unobserved firm effects nevertheless suggests the presence of unobserved firm characteristics that explain both innovation and financial constraints.

\footnotetext{
${ }^{12}$ With the exception of process innovation, where we find a slightly significant cross-equation effect of initial conditions.
} 


\subsection{Financial constraints and firm exit}

Our classification of firms into financially constrained and unconstrained is based on firms' answers to a question in the Community Innovation Survey about whether "availability of finance" constitutes a barrier to innovation. Because of the nature of the survey, this variable is self-reported and may be seen as subjective. The design of our financial constraints measure reflects the qualitative approach of Hoberg and Maksimovic (2015), who employ content analysis to extract information about financial constraints from $10-\mathrm{K}$ statements and find that their index based on disclosures about capitalization and liquidity predicts $R \& D$ and capital expenditures. In line with this approach, and consistently with other studies of financial constraints that use qualitative measures (Kaplan and Zingales, 1994; Whited and Wu, 2006; Hadlock and Pierce, 2010), our results show that financial constraints are more severe in firms that are young, small, and have relatively little cash flow.

A stronger confirmation of the external validity of our financial constraint indicator would be its ability to predict outcomes associated with financial constraints external to the survey. Firms that report constraints are expected to face bankruptcy or cease paying dividends more often than those that do not report constraints (Kaplan and Zingales, 2000). Therefore, a good measure of financial constraints should predict a firm's death. The Business Structure Database of the Office of National Statistics includes demographic events, unlike the Community Innovation Surveys, and we can match these data to our main dataset. Firm death is defined within the BSD as the year in which a firm leaves the Inter-Departmental Business Register (IDBR), a database which is used by UK government for tax and statistical purposes and provides the main sampling frame for surveys carried out by the Office for National Statistics. We construct an indicator for firm death from the BSD year of death for the three-year period following each CIS wave (e.g., we register firm death for the period 2008-2010 and relate it to variables measured in the CIS wave 2006-2008). To estimate the likelihood of firm death, we employ pooled-sample probit models using the full set of CIS firms for which all dependent variables are observed. Out of 5,984 enterprises in a sample of 
9,987 firm-years spanning three CIS waves (death predicted for CIS6 to CIS8), 229 firms can be verified as leaving the sample.

Results of these probit models shown in Table 5 suggest a strong effect of self-reported financial constraints on firm death, despite the loss of demographic events in the matching process. Turnover and firm age are negatively related to firm death, which is expected if informational asymmetries or financial distress indeed drive survey responses to the question about the availability of finance. When we include measures of R\&D and innovation in models 2 to 4 , results reveal a positive effect of $R \& D$ activities, $R \& D$ expenditures and innovation on firm survival. Interestingly, informal R\&D activities predict firm death better than innovation outcomes.

Correlation among R\&D and innovation variables prevents them from becoming significant if all measures are included simultaneously, but a top-down approach starting with a full model and removing insignificant measures of $\mathrm{R} \& \mathrm{D}$ and innovation one by one (results not reported here) suggests that informal internal R\&D activities contribute most to firm survival.

[Table 5 about here]

\section{Additional estimations and robustness checks}

In order to validate our results, we run a series of complementary and additional estimations. First, we compare the results obtained from simultaneous panel models with results generated by simpler models that do not control for reverse causality. We then perform robustness checks on the estimation technique by replacing the Wooldridge (2005) specification of the random effects' means by time averages of these terms as suggested by Mundlak (1978). Finally, we explore and contrast continuous and binary measures of R\&D.

\subsection{Simultaneous vs independent equations}

Tables 6 and 7 show the results of independent estimations of the effects of financial constraints on R\&D (Table 6, Models 1-6) and of R\&D on financial constraints (Table 6, Model 7); and financial 
constraints on innovation (Table 7, Models 1-6) and of innovation on financial constraints (Table 7 , Mode1 7). To demonstrate how different these results are, let us consider as an illustrative example the results presented in Table 6. Some of these show positive effects of financial constraints on $R \& D$, a counter-intuitive result which can be explained by observing the structure of error correlations. Correlation coefficients for firm-year errors between both equations are substantial and significant in almost all our specifications, supporting our modelling strategy. This suggests that the curious positive effect of financial constraints on $R \& D$ and innovation seen in these regressions is caused by unobserved heterogeneity that is correlated between equations.

[Tables 6 and 7 about here]

\subsection{Time-average random effects}

We aim to employ an estimation methodology that models random effects with as many degrees of freedom as possible. The Wooldridge (2005) specification of random effects, however, can lead to a proliferation of nuisance parameters, as each time-varying variable requires as many additional parameters as there are time periods in the data. These additional parameters may be close to redundant and may cause the model to fit the error terms rather than underlying economic relationships. To counter this potential problem, we estimate simpler models using time averages of panel variables (Mundlak, 1978).

Replacing Wooldridge (2005) terms with Mundlak (1978) terms in these alternative models produces results that are almost identical to our main results. Tables 8 and 9 show these robustness tests. All relationships between R\&D and financial constraints in our main results in Table 3 carry over to the robustness tests presented in Table 8 . The negative effect of time-varying turnover on R\&D activities in Table 3 becomes slightly more significant, which is to be expected if degrees of freedom are removed from the model. Foreign ownership, turnover, market scope and human capital remain significant cross-sectional predictors of $R \& D$. The only difference for the $R \& D$ 
equation we find is a reduced effect of a firm's market share on external R\&D. Results for control variables in the financial constraints equation in Tables 3 and 8 are similarly robust to the alternative specification of random effects. A difference can only be observed in the effect of market scope, which is now insignificant where the more comprehensive model in Table 3 was able to distinguish time-varying effects from cross-sectional ones.

[Tables 8 and 9 about here]

When testing our innovation models from Table 4 for robustness to an alternative random effect specification in Table 9, we find similarly stable results. All relationships between innovation indicators and financial constraints within and across equations remain the same, with the sole exception of process innovation, which loses its slightly significant effect on financial constraints. The substantial impact of new-to-the-market innovation, however, remains in place. Time-varying market scope loses some of its significance in favour of its cross-sectional effect on innovation, in line with our findings in robustness tests for R\&D. Market scope also loses its effect on financial constraints, while all other control variables retain their effects. In sum, our findings are robust to a simpler specification using Mundlak (1978) random effects.

\subsection{Continuous vs binary measures of $R \& D$}

Our estimation design is driven by the observation that firms often do not perform any R\&D (Audretsch et al., 2014), while the intensity of R\&D may be a secondary decision once a firm engages in $R \& D$. In principle, a continuous measure of $R \& D$ expenditures is available from the CIS data and would enable a more precise estimation of bi-directional effects in models with financial constraints. However, data restrictions do not allow us to estimate feasible models of R\&D that incorporate the endogeneity of financial constraints while at the same time taking account of a twostage decision process for whether or not to engage in R\&D and its volume. 
However, we try a number of possible specifications to estimate the effect of financial constraints on continuous R\&D expenditures. First, we estimate a cross-sectional OLS model of the natural logarithm of $R \& D$ expenditures using the $R \& D$ equation from our main models above. Coefficients of financial constraints in this regression are similar to the results we obtain from binary single-equation models. Second, instrumenting financial constraints with gross operating profits yields an insignificant effect of financial constraints on $\mathrm{R} \& \mathrm{D}$. Third, to incorporate dynamics into the relationship between $\mathrm{R} \& \mathrm{D}$ expenditures and financial constraints, we estimate the model for R\&D expenditures by system GMM (using all available lags of the dependent variables as GMM-style instruments and the firm's operating margin as IV-style instrument) but find no significant effect of financial constraints. All dynamic models of R\&D expenditures suffer from a lack of observations because observations where R\&D is zero drop out of the sample. This causes many holes in the panels ( $\mathrm{T}=4$ for few firms, mostly $\mathrm{T}=3$ ). Treating non-existent $\mathrm{R} \& \mathrm{D}$ as $£ 1$ when taking logs to retain these observations in the sample does not result in any model improvement.

In summary, running models for continuous $R \& D$ variables does not seem to be feasible with a sample of firms that sometimes start and stop spending on R\&D. A full treatment of this twostage process with a binary R\&D indicator and continuous expenditures would need a third equation and a larger sample, even though the UK already runs a larger survey than most other European countries for which Community Innovation Surveys are available. Adding future CIS waves would certainly be desirable given that we are trying to estimate models with first order dynamics. This would not only increase the precision of coefficients for lagged variables, but also help us disentangle the direct effect of exogenous variables from their correlation with unobserved firm heterogeneity (in Wooldridge coefficients). ${ }^{13}$ Adding a third equation to the system would require

\footnotetext{
${ }^{13}$ An ONS decision to increase sample size seems unlikely at least in the short term, but new models could perhaps use the information contained in the ordinal measure for financial constraints to estimate panel version of ordered response models.
} 
the further development of custom estimation algorithms that can incorporate both binary and continuous dependent variables, as well as greater computing power than is currently available at the ONS's secure data service. However, because the first decision that firms need to make is whether or not to perform $R \& D$ activities, and then decide on the depth of $R \& D$ engagement, we believe our modelling strategy uncovers important and interesting dynamics and constitutes a novel point of departure for further studies with a potential focus on the intensity of R\&D investment as well as the volume of innovation outputs.

\section{Conclusion}

This paper analyses the nature and direction of the relationship between financial constraints and innovation and provides new evidence for a range of innovation inputs and outputs. To the best of our knowledge, this is the first study that compares a broad range of innovation characteristics and models their relationship with financial constraints as a dynamic bivariate process capable of addressing the initial conditions problem through Wooldridge's (2005) method in a panel setting. This allows us for the first time to test theoretical predictions on the effects of a set of innovation activities on firms' capital market access while taking account of reverse causality and dynamic effects. The CIS data cover small and non-listed firms, which are not included in existing studies on the cash-flow sensitivity of investment (e.g., Carpenter and Petersen, 2002), and they provide direct information on the perception of financial constraints combined with detailed information on the innovative profile of firms, covering $R \& D$ expenditures and informal $R \& D$ activities in its internal and external forms as well as several innovation outputs. Hence, our results highlight new aspects of the UK innovation-finance landscape that cannot be easily observed through a traditional cashflow sensitivity approach, which is usually tested on samples of listed large firms. Our validation test of the financial constraints measure also shows that this measure is able to capture consequences of reduced access to external capital.

Our results contain few indications that past financial constraints affect R\&D programs or innovation output. While businesses might be affected by difficulties in raising finance in the short 
term as reflected in their response to the survey question about financial constraints, financing problems do not induce firms to stop their innovative activities altogether. Our results still allow for the possibility that firms reduce the number or intensity of their R\&D projects without completely abandoning their $R \& D$ or innovation programs. The reverse effect of $R \& D$ on financial constraints, which is expected from theory, can be clearly identified in our results.

More surprisingly, there is evidence that innovation, and in particular new-to-market and product innovation, cause financial constraints. This finding has especially important implications for policy: it highlights the fact that the financing challenges of innovation do not stop when firms introduce a new product or service, but continue - and may in fact intensify - in the early stages of technology diffusion. This fact is systematically underestimated or - even more often - completely neglected in the literature. While support for the generation of new products may be vital in many sectors of the economy, support for early firm growth may be at least as important, in particular for SMEs, to build capacity and enable the full exploitation of their innovation activities. Similarly, our results suggest that while specific measures can be useful to alleviate the financial constraints of younger firms, public support may be targeted not primarily at formal R\&D activities (typically covered by $R \& D$ tax credit schemes), but also at informal $R \& D$ activities that do not result in reported R\&D expenditures.

In relation to the broader macroeconomic framework in which this study is set, time effects reflect the impact of the recent financial crisis. Firms were significantly more often financially constrained during 2007/8 than in the preceding period. Financial pressure fell slightly after 2008, but remains high compared with pre-crisis years. While an effect of the crisis can be found in concurrent time effects on financial constraints, investment in research and development lags the macroeconomic climate. Expenditures in R\&D kept increasing until 2008 and only dropped below pre-crisis levels towards the end of the sample period. This finding lends support to the theory that R\&D investment becomes pro-cyclical when firms face tightening credit constraints (Aghion et al., 2012). 
The significant dynamic effects we find are of course only a part of the whole picture. $R \& D$ activities can explain financial constraints, but other firm characteristics correlated with innovation might offer richer insights into the causes of constraints. Unobserved heterogeneity as well as firmyear errors appear to be correlated, which explains implausibly positive effects of financial constraints on innovation generated by simpler models. Future research could aim to address these hidden firm characteristics by collecting and merging additional information about firms' innovative capabilities and financial outlooks. Further methodological developments may also address the problem of integrating information on the volume of $R \& D$ expenditures into a trivariate dynamic model. 


\section{References}

Acharya, V., Xu, Z., 2016. Financial dependence and innovation: The case of public versus private firms. Journal of Financial Economics 124 (2), 223-243.

Acs, Z., Audretsch, D., 1990. Innovation and small firms, MIT Press, Boston.

Aghion, P., Askenazy, P., Berman, N., Cette, G., Eymard, L., 2012. Credit constraints and the cyclicality of R\&D investment: Evidence from France. Journal of the European Economic Association 10 (5), 1001-1024.

Aghion, P., Akcigit, U., Howitt, P., 2013. What do we learn from Schumpeterian growth theory? NBER working paper no. 18824.

Aghion, P., Bloom, N., Blundell, R., Griffith, R. and Howitt, P., 2005. Competition and innovation: An inverted-U relationship, Quarterly Journal of Economics 120 (2), 701-728.

Almeida, H., Campello, M., 2007. Financial constraints, asset tangibility, and corporate investment. Review of Financial Studies 20 (5), 1429-1460.

Amore, M. D., Schneider, C., Žaldokas, A., 2013. Credit supply and corporate innovation. Journal of Financial Economics 109 (3), 835-855.

Audretsch, D. B., Segarra, A., Teruel, M., 2014. Why don't all young firms invest in R\&D? Small Business Economics 43 (4), 751-766.

Bah, R., Dumontier, P., 2001. R\&D intensity and corporate financial policy: Some international evidence. Journal of Business Finance and Accounting 28 (5-6), 671-692.

Behr, P., Norden, L., Noth, F., 2013. Financial constraints of private firms and bank lending behavior. Journal of Banking and Finance 37 (9), 3472-3485.

Blundell, R., Griffith, R., Van Reenen, J., 1999. Market share, market value and innovation in a panel of British manufacturing firms. Review of Economic Studies 66 (3), 529-554.

Bond, S., Elston, J., Mairesse, J., Mulkay, B., 2003. Financial factors and investment in Belgium, France, Germany, and the United Kingdom: A comparison using company panel data. Review of Economics and Statistics 85 (1), 153-165.

Bond, S., Harhoff, D., Van Reenen, J., 2005. Investment, R\&D, and financial constraints in Britain and Germany. Annales d'Economie et de Statistique 79/80, 433-460.

Bond, S., Meghir, C., 1994. Dynamic investment models and the firm's financial policy. Review of Economic Studies 61 (2), 197-222.

Bond, S., Van Reenen, J., 2007. Microeconometric models of investment and employment. In: Heckman, J. J., and Leamer, E. E. (Eds.), Handbook of Econometrics 6A. Elsevier, Boston, pp. 4417-4498.

Breschi, S., Malerba, F., Orsenigo, L., 2000. Technological regimes and Schumpeterian patterns of innovation. Economic Journal 110 (463), 388-410.

Brown, J. R., Fazzari, S. M., Petersen, B. C., 2009. Financing innovation and growth: Cash flow, external equity, and the 1990s R\&D boom. Journal of Finance 64 (1), 151-185.

Brown, J. R., Martinsson, G., Petersen, B. C., 2012. Do financing constraints matter for R\&D? European Economic Review 56 (8), 1512-1529.

Brown, J. R., Petersen, B. C., 2009. Why has the investment-cash flow sensitivity declined so sharply? Rising R\&D and equity market developments. Journal of Banking and Finance 33 (5), 971-984. 
Brown, J. R., Petersen, B. C., 2011. Cash holdings and R\&D smoothing. Journal of Corporate Finance 17 (3), 694-709.

Canepa, A., Stoneman, P., 2007. Financial constraints to innovation in the UK: Evidence from CIS2 and CIS3. Oxford Economics Papers 60 (4), 711-730.

Carpenter, R. E., Fazzari, S. M., Petersen, B. C., 1998. Financing constraints and inventory investment: A comparative study with high-frequency panel data. Review of Economics and Statistics 80 (4), 513-519.

Carpenter, R. E., Petersen, B. C., 2002. Is the growth of small firms constrained by internal finance? Review of Economics and Statistics 84 (2), 298-309.

Chava, S., Oettl, A., Subramanian, A., Subramanian, K. V., 2013. Banking deregulation and innovation. Journal of Financial Economics 109 (3), 759-774.

Cincera, M., Ravet, J., 2010. Financing constraints and R\&D investments of large corporations in Europe and the US. Science and Public Policy 37 (6), 455-466.

Cleary, S., 1999. The relationship between firm investment and financial status. Journal of Finance 54 (2), 673-692.

Cleary, S., Povel, P., Raith, M., 2007. The U-shaped investment curve: Theory and evidence. Journal of Financial and Quantitative Analysis 42 (1), 1-40.

Coad, A., 2010. Neoclassical vs evolutionary theories of financial constraints: Critique and prospectus. Structural Change and Economic Dynamics 21 (3), 206-218.

Cohen, W. M., 2010. Fifty years of empirical studies of innovative activity and performance. In: Hall, B. H., Rosenberg, N. (Eds.), Handbook of the Economics of Innovation, Ch. 4, 129-213, Elsevier.

Chen, H., Chen, S., 2012. Investment cash flow sensitivity cannot be a good measure of financial constraints: Evidence from the time series. Journal of Financial Economics 103 (2), 93-410.

Cornaggia, J., Mao, Y., Tian, X., Wolfe, B., 2015. Does banking competition affect innovation? Journal of Financial Economics 115 (1), 189-209.

Cosh, A., Cumming, D., Hughes, D., 2009. Outside entrepreneurial capital. Economic Journal 119 (540), 1494-1533.

Crepon, B., Duguet, E., Mairesse, J., 1998. Research, innovation, and productivity: An econometric analysis at the firm level. Economics of Innovation and New Technology 7 (2), 115-158.

Czarnitzki, D., Hottenrott, H., 2011. Financial constraints: Routine versus cutting edge R\&D investment. Journal of Economics \& Management Strategy 20 (1), 121-157.

D'Este, P., Iammarino, S., Savona, M., von Tunzelmann, N., 2012. What hampers innovation? Revealed barriers versus deterring barriers, Research Policy 41 (2), 482-488.

Dosi, G., 1988. Sources, procedures and microeconomic effects of innovation. Journal of Economic Literature 26 (3), 1120-1171.

Farre-Mensa, J., Ljungqvist, A., 2016. Do Measures of Financial Constraints Measure Financial Constraints? Review of Financial Studies 29 (2), 271-308.

Fazzari, S., Hubbard, R. G., Petersen, B. C., 1988. Financing constraints and corporate investment. Brookings Papers on Economic Activity 1, 141-206.

Fazzari, S., Hubbard, R. G., Petersen, B. C., 2000. Investment-cash flow sensitivities are useful: A comment on Kaplan and Zingales. Quarterly Journal of Economics 115 (2), 695-705.

Geroski, P., Machin, S., Van Reenen, J., 1993. The profitability of innovating firms. The RAND Journal of Economics 24 (2), 198-211. 
Gompers, P. A., 1995.Optimal investment, monitoring, and the staging of venture capital. Journal of Finance 50 (5), 1461-1489.

Gouriéroux, C., Monfort, A., 1996. Simulation-based econometric methods.Oxford University Press, Oxford.

Hajivassiliou, V., Savignac, F., 2016. Financing constraints and a firm's decision and ability to innovate: Novel approaches to coherency conditions in dynamic LDV models. LSE Department of Economics working paper, http://econ.lse.ac.uk/staff/vassilis/pub/papers/pdf/financing_constraints_innovation.pdf.

Hadlock, C., Pierce, J., 2010. New evidence on measuring financial constraints: Moving beyond the KZ index. Review of Financial Studies 23 (5),1909-1940.

Hall, B. H., 1992. Investment and research and development at the firm level: Does the source of financing matter? NBER working paper no. 4096.

Hall, B. H., 2002. The financing of research and development. Oxford Review of Economic Policy $18(1), 35-51$.

Hall, B. H., 2010. The financing of innovative firms. Review of Economics and Institutions 1 (1), $1-30$.

Hall, B. H., Lerner, J., 2010. The financing of R\&D and innovation. In: Hall, B. H., and Rosenberg, N. (Eds.), Handbook of the economics of innovation, Vol. 1, 609-639, North Holland.

Harhoff, D., 1998. Are there financing constraints for R\&D and investment in German manufacturing firms? Annales d'Économie et de Statistique 49/50, 421-456.

Himmelberg, C. P., Petersen, B. C., 1994. R\&D and internal finance: A panel study of small firms in high-tech industries. Review of Economics and Statistics 76 (1), 38-51.

Hoberg, G., Maksimovic, V., 2015. Redefining financial constraints: A text-based analysis. Review of Financial Studies 28 (5), 1312-1352.

Hoegl, M., Gibbert, M., Mazursky, D., 2008. Financial constraints in innovation projects: When is less more? Research Policy 37 (8), 1382-1391.

Hottenrott, H., Peters, B., 2012. Innovative capability and financing constraints for innovation: more money, more innovation? Review of Economics and Statistics 94 (4), 1126-1142.

Howell, A., 2016. Firm R\&D, innovation and easing financial constraints in China: Does corporate tax reform matter? Research Policy 45 (10), 1996-2007.

$\mathrm{Hu}, \mathrm{X}$., Schiantarelli, F., 1998. Investment and capital market imperfections: A switching regression approach using U.S. firm panel data. Review of Economics and Statistics 80 (3), 466-479.

Hubbard, R. G., 1998. Capital-market imperfections and investment. Journal of Economic Literature 36 (1), 193-225.

Jaffe, A. B., Trajtenberg, M., 2002. Patents, citations and innovations: A window on the knowledge economy. MIT Press, Cambridge, Mass.

Kahle, K. M., Stulz, R., 2013. Access to capital, investment, and the financial crisis. Journal of Financial Economics 110 (2), 280-299.

Kaplan, S. N., Zingales, L., 1997. Do investment-cash flow sensitivities provide useful measures of financing constraints? Quarterly Journal of Economics 112 (1), 169-215.

Kaplan, S. N., Zingales, L., 2000. Investment-cash flow sensitivities are not valid measures of financing constraints. Quarterly Journal of Economics 115 (2), 707-712.

Kayo, E. K., Kimura, H., 2011. Hierarchical determinants of capital structure. Journal of Banking and Finance 35 (2), 358-371. 
Kline, S. J., Rosenberg, N., 1986. An overview of innovation, In: Landau, R., Rosenberg, N. (Eds.), The positive sum strategy: Harnessing technology for economic growth. National Academy Press, Washington, DC, pp. 275-305.

Koh, P.-S., Reeb, D., 2015. Missing R\&D. Journal of Accounting and Economics 60 (1), 73-94.

Krasker, W., 1986. Stock price movements in response to stock issues under asymmetric information, Journal of Finance 41 (1), 93-105.

Lamont, O., Polk, C., Saá-Requejo, J., 2001. Financial constraints and stock returns. Review of Financial Studies 14 (2), 529-554.

Lee, N., Sameen, H., Cowling, M., 2015. Access to finance for innovative SMEs since the financial crisis. Research Policy 44 (2), 370-380.

Mancusi, M. L., Vezzulli, A., 2014. R\&D and credit rationing in SMEs. Economic Enquiry 52 (3), $1153-1172$.

Mohnen, P., Palm, F. C., van der Loeff, S. S., Tiwari, A. K., 2008. Financial constraints and other obstacles: Are they a threat to innovation activity? De Economist 156 (2), 201-214.

Müller, E., Zimmermann, V., 2009. The importance of equity finance for R\&D activity. Small Business Economics 33 (3), 303-318.

Mulier, K., Schoors, K., Merlevede, B., 2016. Investment-cash flow sensitivity and financial constraints: Evidence from unquoted European SMEs. Journal of Banking and Finance 73, $182-197$.

Mulkay, B., Hall, B. B., Mairesse, J., 2000. Firm level investment and R\&D in France and the United States: A comparison. NBER working paper no. 8038.

Mundlak, Y., 1978. On the pooling of time series and cross section data. Econometrica 46 (1), 69 85 .

Myers, S. C., Majluf, N. S., 1984. Corporate financing and investment decisions when firms have information that investors do not have. Journal of Financial Economics 13 (2), 187-221.

OECD, 2005. OECD science, technology and industry scoreboard. OECD Publishing, Paris.

OECD, 2009. Policy responses to the economic crisis: Investing in innovation for long-term growth. Paris: OECD, http://www.oecd.org/sti/42983414.pdf.

Pellegrino, G., Savona, M., 2017. No money, no honey? Financial versus knowledge and demand constraints on innovation. Research Policy 46 (2), 510-521.

Riddick, L. A., Whited, T. M., 2009. The corporate propensity to save. Journal of Finance 64 (4), 1729-1766.

Rosenberg, N., 1994. Exploring the black box: Technology, economics, and history. Cambridge University Press, Cambridge.

Savignac, F., 2008. The impact of financial constraints on innovation: What can be learned from a direct measure? Economics of Innovation and New Technology 17 (6), 553-569.

Santamaría, L., Nieto, M.J., Barge-Gil, A., 2009. Beyond formal R\&D: Taking advantage of other sources of innovation in low- and medium-technology industries. Research Policy 38 (3), $507-517$.

Scherer, F. M., 1984. Innovation and growth: Schumpeterian perspectives. MIT Press, Boston.

Scherer, F. M., 1999. New perspectives on economic growth and technological innovation.

Brookings Institution Press, Washington, DC. 
Schiantarelli, F., 1996. Financial constraints and investment: Methodological issues and international evidence. Oxford Review of Economic Policy 12 (2), 70-89.

Schumpeter, J. A., 1934. The theory of economic development. Harvard University Press, Cambridge, MA.

Schumpeter, J. A., 1942. Capitalism, socialism and democracy. Harper and Brothers, New York.

Silva, F., Carreira, C., 2012. Do financial constraints threat the innovation process? Evidence from Portuguese Firms. Economics of Innovation and New Technology 21 (8), 701-736.

Stoneman, P., 2001. The economics of technological diffusion. Blackwell, Oxford.

Teece, D. J., 1992. Competition, cooperation, and innovation: Organizational arrangements for regimes of rapid technological progress. Journal of Economic Behavior and Organization 18 (1), 1-25.

Teece, D. J., 2010. Technological innovation and the theory of the firm: The role of enterprise-level knowledge, complementarities, and (dynamic) capabilities. In: Hall, B. H., Rosenberg, N. (Eds.) Handbook of the Economics of Innovation, vol. 1, North Holland/Elsevier, Amsterdam, pp. 679-730.

Train, K. E., 2009. Discrete choice methods with simulation. Cambridge University Press, Cambridge.

Tversky, A., Kahneman, D., 1973. Availability: A heuristic for judging frequency and probability. Cognitive Psychology 5 (2), 207-232.

Westhead, P., Storey, D., 1997. Financial constraints on the growth of high technology small firms in the United Kingdom. Applied Financial Economics 7 (2), 197-201.

Whited, T. M., 1992. Debt, liquidity constraints and corporate investment: Evidence from panel data. Journal of Finance 47 (4), 1425-1460.

Whited, T. M., Wu, G., 2006. Financial constraints risk. Review of Financial Studies 19 (2), 531559.

Wooldridge, J. M., 2005. Simple solutions to the initial conditions problem in dynamic, nonlinear panel data models with unobserved heterogeneity. Journal of Applied Econometrics 20 (1), $39-54$. 
Table 1

Descriptive statistics

Panel A. Summary statistics

Panel (p),

cross-section (i),

\begin{tabular}{|c|c|c|c|c|c|c|}
\hline Variable & $\mathrm{N}$ & Min & Max & Mean & $\mathrm{SD}$ & or time $(\mathrm{t})$ \\
\hline R\&D internal (expenditure) & 10402 & 0 & 1 & 0.279 & 0.448 & $\mathrm{p}$ \\
\hline R\&D external (expenditure) & 10402 & 0 & 1 & 0.104 & 0.305 & $\mathrm{p}$ \\
\hline R\&D any (expenditure) & 10402 & 0 & 1 & 0.296 & 0.456 & $\mathrm{p}$ \\
\hline R\&D internal (activity) & 10266 & 0 & 1 & 0.345 & 0.475 & $\mathrm{p}$ \\
\hline R\&D external (activity) & 10253 & 0 & 1 & 0.136 & 0.343 & $\mathrm{p}$ \\
\hline R\&D any (activity) & 10259 & 0 & 1 & 0.363 & 0.481 & $\mathrm{p}$ \\
\hline Innovation (any) & 10377 & 0 & 1 & 0.343 & 0.475 & $\mathrm{p}$ \\
\hline Innovation new to market & 10251 & 0 & 1 & 0.134 & 0.340 & $\mathrm{p}$ \\
\hline Innovation new to firm & 10249 & 0 & 1 & 0.128 & 0.334 & $\mathrm{p}$ \\
\hline Innovation (good) & 10382 & 0 & 1 & 0.190 & 0.392 & $\mathrm{p}$ \\
\hline Innovation (process) & 10385 & 0 & 1 & 0.186 & 0.389 & $\mathrm{p}$ \\
\hline Innovation (service) & 10379 & 0 & 1 & 0.179 & 0.384 & $\mathrm{p}$ \\
\hline Fin. constraint & 10258 & 0 & 1 & 0.245 & 0.430 & $\mathrm{p}$ \\
\hline Turnover $(\log )$ & 6995 & $(0,7.5]$ & $(9.5,17.5]$ & 8.668 & 1.881 & $\mathrm{p}$ \\
\hline Observations in interval & & 2159 & 2185 & & & \\
\hline Market scope & 6995 & 1 & 4 & 2.337 & 1.135 & $\mathrm{p}$ \\
\hline Human Capital & 6995 & {$[0]$} & $(0.5,2]$ & 0.137 & 0.237 & $\mathrm{p}$ \\
\hline Observations in interval & & 2260 & 562 & & & \\
\hline Operating margin & 6995 & $(-1.1,0]$ & $(0.15,1]$ & 0.105 & 0.136 & $\mathrm{p}$ \\
\hline Observations in interval & & 797 & 1842 & & & \\
\hline Market share & 6995 & $(-13.5,-8]$ & $(-6,0]$ & -6.728 & 2.191 & $\mathrm{p}$ \\
\hline Observations in interval & & 2182 & 2460 & & & \\
\hline Age $(\log )$ & 6995 & $(0,2.5]$ & $(3.9,4.1]$ & 3.234 & 0.558 & $\mathrm{i}$ \\
\hline Observations in interval & & 796 & 1728 & & & \\
\hline Group member & 6995 & 0 & 1 & 0.352 & 0.478 & $\mathrm{i}$ \\
\hline Company & 6995 & 0 & 1 & 0.864 & 0.343 & $\mathrm{i}$ \\
\hline Foreign ownership & 6995 & 0 & 1 & 0.121 & 0.326 & $\mathrm{i}$ \\
\hline Sector: Construction & 6995 & 0 & 1 & 0.076 & 0.265 & $\mathrm{i}$ \\
\hline Sector: Financial & 6995 & 0 & 1 & 0.031 & 0.172 & $\mathrm{i}$ \\
\hline Sector: Hotels, Restaurants & 6995 & 0 & 1 & 0.055 & 0.228 & $\mathrm{i}$ \\
\hline Sector: $R \& D$ services & 6995 & 0 & 1 & 0.031 & 0.173 & $\mathrm{i}$ \\
\hline Sector: Med./High-tech manuf. & 6995 & 0 & 1 & 0.106 & 0.308 & $\mathrm{i}$ \\
\hline Sector: Med./Low-tech manuf. & 6995 & 0 & 1 & 0.221 & 0.415 & $\mathrm{i}$ \\
\hline Sector: Other Services & 6995 & 0 & 1 & 0.199 & 0.399 & $\mathrm{i}$ \\
\hline Sector: Trade & 6995 & 0 & 1 & 0.177 & 0.382 & $\mathrm{i}$ \\
\hline Sector: Transport & 6995 & 0 & 1 & 0.082 & 0.275 & $\mathrm{i}$ \\
\hline Sector: Other & 6995 & 0 & 1 & 0.021 & 0.145 & $\mathrm{i}$ \\
\hline Time effect CIS5 & 6995 & 0 & 1 & 0.456 & 0.498 & $\mathrm{t}$ \\
\hline Time effect CIS6 & 6995 & 0 & 1 & 0.460 & 0.498 & $\mathrm{t}$ \\
\hline Time effect CIS7 & 6995 & 0 & 1 & 0.084 & 0.278 & $\mathrm{t}$ \\
\hline
\end{tabular}


Table 1 (continued)

Panel B. Variable definitions

Variable

Definition

R\&D internal (expenditure)

The firm's stated amount of internal R\&D expenditures is positive in the last year of the survey period (e.g., in 2008 for the period 2006-2008). Dummy variable.

R\&D external (expenditure) The firm's stated amount of external R\&D expenditures is positive in the last year of the survey period (e.g., in 2008 for the period 2006-2008). Dummy variable.

R\&D any (expenditure)

R\&D internal (activity)

The firm states positive internal or external R\&D expenditures.

The firm engaged in creative work on an occasional or regular basis to increase the stock of knowledge or used it to devise new and improved goods, services and processes. Dummy variable.

R\&D external (activity)

The firm engaged in external R\&D activities; same as internal R\&D, but purchased by the firm and performed by other companies (including other businesses within its group) or by public or private research organisations. Dummy variable.

R\&D any (activity) Innovation (any) Innovation new to market

Innovation new to firm

Innovation (good) Innovation (process) Innovation (service)

Fin. constraint

Turnover $(\log )$

The firm engaged in internal or external $R \& D$ activities

The firm introduced any kind of innovation as defined below.

The firm introduced a new good or service onto the market before its competitors. Dummy variable.

The firm introduced a new good or service that was essentially the same as a product already available from its competitors. Dummy variable.

The firm introduced new or significantly improved goods.

The firm introduced any new or significantly improved processes for producing or supplying products.

The firm introduced new or significantly improved services.

The firm faced constraints in the availability of finance. This dummy variable is derived from the corresponding survey question "How important were the following factors as constraints on innovation activities in influencing a decision not to innovate?" Firms answering "not experienced" or "low" are treated as not being financially constrained, while those answering "medium" or "high" are defined as financially constrained.

The firm's turnover in GBP (thousands, natural logarithm) for the last year of the survey period. This variable is lagged by one period. For a small number of firm, turnover was missing, but could be recovered from the corresponding entries in the Business Structure Database (BSD). Reading example: There are 2159 observation in the interval $[0,7.5]$.

Market scope

Human Capital

The largest geographic market in which a firm sells goods or services. Possible answers are 1="Local/regional within the UK", 2="UK", 3="Other Europe" and 4="All other countries".

The proportion of a firm's employees in the last year of the survey period that were educated to degree level or above. The maximum value is 2 , since this variable adds the survey items "science or engineering subjects" and "other subjects". This variable is lagged by one period.

Operating margin

Operating margin, defined as gross value added at factor cost minus total labour cost, divided by turnover. A firm's operating margin is calculated for the first year of the relevant CIS wave. For example, the operating margin used to predict dependent variables in CIS7 (2008-2010) is from 2008. About 59\% of all observations for this variable have been imputed using regression imputation.

Market share

Market share of the firm, defined as the firm's turnover divided by concurrent total market turnover. A market is defined based on five-digit SIC2007 codes, using the full sample and sampling weights of the Annual Respondents Database (ARD). About $2 \%$ of all observations for this variable have been imputed using regression imputation.

Age $(\log )$

Firm age (natural logarithm) calculated as (2010 minus birth year). Firm birth is censored at 1973 in the Business Structure Database. In order to avoid potential biases due to censored right-hand variables, we impute censored values using predicted values from a tobit regression of birth year on all other independent variables. This places many observations in the interval $(3.8,4.1]$.

Group member Company

Foreign ownership Sector: Construction

Sector: Financial

Sector: Hotels, Restaurants

Sector: R\&D services

Sector: Med./High-tech manuf

Sector: Med./Low-tech manuf.

Sector: Other Services

Sector: Trade

Sector: Transport

Sector: Other

Time effect CIS5

Time effect CIS6

Time effect CIS7

The firm is part of an enterprise group in the first period (CIS4). Dummy variable.

The firm has status "company" as opposed to sole proprietorship etc. in the Business Structure Database. Dummy variable.

The firm is under foreign ownership (ultimately) in CIS5 (2004-2006). Dummy variable.

SIC (1992, UK) codes beginning with: 45

SIC (1992, UK) codes beginning with: 35, 24, 30, 32, 33, 31, 34, 29

SIC (1992, UK) codes beginning with: 25, 23, 26, 27, 28, 36, 37, 20, 21, 22, 15, 16, 17, 18,19

SIC (1992, UK) codes beginning with: 55

SIC (1992, UK) codes beginning with: 65,67

SIC (1992, UK) codes beginning with: 72,73

SIC (1992, UK) codes beginning with: 70, 71, 74, 90-99

SIC (1992, UK) codes beginning with: $50-52$

SIC (1992, UK) codes beginning with: $60-63$

SIC (1992, UK) codes beginning with: 10-14, 75, 80, 85 (Mining, Utilities, Education, Public Administration, Health)

Time dummy for CIS5 (period 2004-2006)

Time dummy for CIS6 (period 2006-2008)

Time dummy for CIS7 (period 2008-2010)

Notes: This table shows summary statistics and definitions for the variables used in our analyses. Exact minimum, maximum and median values cannot be shown due to rules regulating statistical disclosure at the Secure Data Service/ONS. Instead, we provide frequency statistics for intervals containing the minimum and maximum under the "Min" and "Max" headings for continuous variables. The number of observations is the maximum number of observations for all time periods for panel variables (p), crosssectional variables (i) and time variables (t). Due to missing variables in dependent variables, individual analyses may have slightly fewer observations. For independent variables, there are 2659 two-period panels and 559 three-period panels, which yields 3218 panels with a maximum of 6995 observations in total for independent variables in bivariate panel analysis. Dependent variables have more observations, since the first observation for each firm is used up for lagged dependent variables. 
Table 2

Transition matrices for dependent variables

\begin{tabular}{|c|c|c|c|c|c|c|c|c|c|c|}
\hline \multirow{2}{*}{$\begin{array}{l}\text { Panel A. } R \& D \\
\text { R\&D (any) / } \\
\text { Financial constraints in } \mathrm{t}\end{array}$} & \multicolumn{8}{|c|}{$R \& D$ (any) / Financial constraints in $t+1$} & \multirow[b]{2}{*}{ Total } & \multirow[b]{2}{*}{$\%$} \\
\hline & $\mathrm{No} / \mathrm{No}$ & $\%$ & $\mathrm{No} / \mathrm{Yes}$ & $\%$ & Yes/No & $\%$ & Yes/Yes & $\%$ & & \\
\hline $\mathrm{No} / \mathrm{No}$ & 2514 & 36.2 & 459 & 6.6 & 537 & 7.7 & 179 & 2.6 & 3689 & 53.1 \\
\hline $\mathrm{No} / \mathrm{Yes}$ & 352 & 5.1 & 237 & 3.4 & 96 & 1.4 & 82 & 1.2 & 767 & 11.0 \\
\hline Yes/No & 476 & 6.8 & 111 & 1.6 & 880 & 12.7 & 303 & 4.4 & 1770 & 25.5 \\
\hline Yes/Yes & 150 & 2.2 & 85 & 1.2 & 193 & 2.8 & 296 & 4.3 & 724 & 10.4 \\
\hline Total & 3492 & 50.2 & 892 & 12.8 & 1706 & 24.5 & 860 & 12.4 & 6950 & 100.0 \\
\hline Panel B. Innovation & \multicolumn{8}{|c|}{ Innovation (any) / Financial constraints in $\mathrm{t}+1$} & & \\
\hline $\begin{array}{l}\text { Innovation (any) / } \\
\text { Financial constraints in } \mathrm{t}\end{array}$ & No/No & $\%$ & $\mathrm{No} / \mathrm{Yes}$ & $\%$ & Yes/No & $\%$ & Yes/Yes & $\%$ & Total & $\%$ \\
\hline $\mathrm{No} / \mathrm{No}$ & 2622 & 37.3 & 487 & 6.9 & 491 & 7.0 & 192 & 2.7 & 3792 & 54.0 \\
\hline $\mathrm{No} / \mathrm{Yes}$ & 357 & 5.1 & 235 & 3.3 & 87 & 1.2 & 102 & 1.5 & 781 & 11.1 \\
\hline Yes/No & 598 & 8.5 & 133 & 1.9 & 754 & 10.7 & 247 & 3.5 & 1732 & 24.6 \\
\hline Yes/Yes & 179 & 2.5 & 111 & 1.6 & 182 & 2.6 & 251 & 3.6 & 723 & 10.3 \\
\hline Total & 3756 & 53.4 & 966 & 13.7 & 1514 & 21.5 & 792 & 11.3 & 7028 & 100.0 \\
\hline
\end{tabular}

Notes: This table shows the number of transitions between R\&D and financial constraints states during the whole sample period. Each firm has two state variables that correspond to our dependent variables: whether it performs any research and development (or produces an innovation) and whether it experiences financial constraints in a given CIS round. For example, a firm can perform R\&D and not experience financial constraint in period $t$ ("Yes/No" in leftmost column) and transition to no R\&D, but financial constraints in period $\mathrm{t}+1$ (column "No/Yes"). This state transition would add one observation to the cell ("Yes/No", "No/Yes"). Cells represent the sum of all such transitions over all CIS rounds. The lower panel shows state transitions for the innovation variable that measures whether a firm produces any kind of innovation in period $t$. 
Table 3

Research and development: simultaneous equations

\begin{tabular}{|c|c|c|c|c|c|c|}
\hline $\begin{array}{l}\text { Dependent variable } \\
\text { in } R \& D \text { equation }\end{array}$ & $\begin{array}{c}\text { R\&D any } \\
\text { (expenditure) }\end{array}$ & $\begin{array}{l}\text { R\&D any } \\
\text { (activity) }\end{array}$ & $\begin{array}{l}\text { R\&D external } \\
\text { (expenditure) }\end{array}$ & $\begin{array}{l}\text { R\&D external } \\
\text { (activity) }\end{array}$ & $\begin{array}{l}\text { R\&D internal } \\
\text { (expenditure) }\end{array}$ & $\begin{array}{l}\text { R\&D internal } \\
\text { (activity) }\end{array}$ \\
\hline \multicolumn{7}{|l|}{ Dependent: R\&D } \\
\hline R\&D (lag) & $0.380(0.089)^{* * *}$ & $0.364(0.086)^{* * *}$ & $0.588(0.106)^{* * *}$ & $0.410(0.110)^{* * *}$ & $0.372(0.093)^{* * *}$ & $0.358(0.090)^{* * *}$ \\
\hline Fin. constraints (lag) & $-0.067(0.085)$ & $0.035(0.081)$ & $-0.134(0.087)$ & $-0.195(0.088)^{* *}$ & $-0.033(0.090)$ & $0.044(0.084)$ \\
\hline Turnover (log) (lag) & $-0.025(0.043)$ & $-0.073(0.039)^{*}$ & $-0.018(0.053)$ & $0.001(0.050)$ & $-0.022(0.045)$ & $-0.085(0.041)^{* *}$ \\
\hline Market scope & $0.022(0.054)$ & $0.072(0.047)$ & $0.033(0.073)$ & $0.055(0.062)$ & $0.014(0.056)$ & $0.079(0.049)$ \\
\hline Human capital (lag) & $0.025(0.171)$ & $0.020(0.162)$ & $-0.231(0.202)$ & $-0.162(0.191)$ & $0.096(0.172)$ & $0.038(0.158)$ \\
\hline Market share (lag) & $0.013(0.032)$ & $0.048(0.027)^{*}$ & $0.058(0.043)$ & $0.053(0.038)$ & $0.007(0.033)$ & $0.032(0.028)$ \\
\hline Age $(\log )$ & $0.010(0.047)$ & $0.001(0.046)$ & $-0.023(0.049)$ & $-0.059(0.049)$ & $0.000(0.049)$ & $0.005(0.047)$ \\
\hline Group member & $-0.045(0.058)$ & $-0.051(0.056)$ & $0.045(0.058)$ & $0.004(0.061)$ & $-0.076(0.061)$ & $-0.078(0.059)$ \\
\hline Company & $0.116(0.086)$ & $0.060(0.079)$ & $0.067(0.091)$ & $0.015(0.089)$ & $0.118(0.091)$ & $0.038(0.082)$ \\
\hline Foreign ownership & $-0.323(0.082)^{* * *}$ & $-0.164(0.080)^{* *}$ & $-0.062(0.077)$ & $0.015(0.081)$ & $-0.310(0.086)^{* * *}$ & $-0.205(0.082)^{* *}$ \\
\hline Time effect CIS6 & $0.103(0.043)^{* *}$ & $0.160(0.041)^{* * *}$ & $-0.071(0.051)$ & $-0.003(0.048)$ & $0.105(0.044)^{* *}$ & $0.171(0.042)^{* * *}$ \\
\hline Time effect CIS7 & $-0.165(0.091)^{*}$ & $-0.229(0.085)^{* * *}$ & $-0.061(0.107)$ & $-0.011(0.107)$ & $-0.211(0.097)^{* *}$ & $-0.269(0.089) * * *$ \\
\hline Industry effects & Yes & Yes & Yes & Yes & Yes & Yes \\
\hline \multicolumn{7}{|l|}{ Wooldridge terms } \\
\hline R\&D in CIS4 & $0.899(0.106)^{* * *}$ & $0.833(0.100)^{* * *}$ & $0.618(0.115)^{* * *}$ & $0.753(0.118)^{* * *}$ & $0.949(0.113)^{* * *}$ & $0.874(0.106)^{* * *}$ \\
\hline Fin. constr. in CIS4 & $0.173(0.076)^{* *}$ & $0.105(0.075)$ & $0.112(0.078)$ & $0.198(0.080)^{* *}$ & $0.149(0.080)^{*}$ & $0.114(0.076)$ \\
\hline Turnover (log), CIS4 & $-0.024(0.022)$ & $-0.012(0.021)$ & $0.004(0.023)$ & $0.007(0.022)$ & $-0.029(0.023)$ & $-0.018(0.021)$ \\
\hline Turnover (log), CIS5 & $-0.044(0.058)$ & $0.021(0.052)$ & $-0.055(0.064)$ & $-0.033(0.064)$ & $-0.063(0.060)$ & $0.014(0.054)$ \\
\hline Turnover (log), CIS6 & $0.165(0.051)^{* * *}$ & $0.131(0.047)^{* * *}$ & $0.139(0.057)^{* *}$ & $0.129(0.055)^{* *}$ & $0.173(0.053)^{* * *}$ & $0.143(0.048)^{* * *}$ \\
\hline Market scope, CIS5 & $0.147(0.047)^{* * *}$ & $0.107(0.045)^{* *}$ & $0.088(0.058)$ & $0.076(0.052)$ & $0.162(0.048)^{* * *}$ & $0.110(0.046)^{* *}$ \\
\hline Market scope, CIS6 & $0.078(0.048)$ & $0.059(0.046)$ & $0.013(0.056)$ & $0.024(0.054)$ & $0.093(0.051)^{*}$ & $0.070(0.048)$ \\
\hline Market scope, CIS7 & $0.030(0.031)$ & $0.011(0.031)$ & $0.024(0.030)$ & $0.023(0.030)$ & $0.038(0.033)$ & $0.020(0.032)$ \\
\hline Human capital, CIS4 & $-0.040(0.158)$ & $-0.134(0.158)$ & $0.218(0.159)$ & $0.205(0.161)$ & $-0.159(0.163)$ & $-0.193(0.165)$ \\
\hline Human capital, CIS5 & $0.110(0.149)$ & $0.113(0.145)$ & $0.121(0.150)$ & $0.081(0.165)$ & $0.062(0.158)$ & $0.071(0.154)$ \\
\hline Human capital, CIS6 & $0.646(0.155)^{* * *}$ & $0.726(0.158)^{* * *}$ & $0.271(0.163)^{*}$ & $0.263(0.168)$ & $0.697(0.166)^{* * *}$ & $0.815(0.165)^{* * *}$ \\
\hline Market share, CIS4 & $0.000(0.035)$ & $-0.007(0.035)$ & $0.029(0.046)$ & $0.032(0.043)$ & $-0.007(0.037)$ & $0.010(0.035)$ \\
\hline Market share, CIS5 & $0.013(0.033)$ & $-0.007(0.033)$ & $-0.041(0.043)$ & $-0.053(0.044)$ & $0.026(0.034)$ & $-0.007(0.033)$ \\
\hline Market share, CIS6 & $0.022(0.014)$ & $0.018(0.014)$ & $0.034(0.015)^{* *}$ & $0.047(0.015)^{* * *}$ & $0.021(0.015)$ & $0.013(0.014)$ \\
\hline \multicolumn{7}{|c|}{ Dependent: Financial constraints } \\
\hline R\&D (lag) & $0.051(0.075)$ & $0.209(0.076)^{* * *}$ & $0.138(0.087)$ & $0.079(0.084)$ & $0.025(0.078)$ & $0.149(0.077)^{*}$ \\
\hline Fin. constraints (lag) & $0.486(0.069)^{* * *}$ & $0.519(0.067)^{* * *}$ & $0.476(0.072)^{* * *}$ & $0.474(0.072)^{* * *}$ & $0.485(0.069)^{* * *}$ & $0.445(0.075)^{* * *}$ \\
\hline Turnover (log) (lag) & $0.047(0.037)$ & $0.044(0.038)$ & $0.048(0.038)$ & $0.048(0.038)$ & $0.046(0.037)$ & $0.045(0.039)$ \\
\hline Market scope & $0.103(0.050)^{* *}$ & $0.109(0.051)^{* *}$ & $0.105(0.050)^{* *}$ & $0.100(0.051)^{*}$ & $0.103(0.050)^{* *}$ & $0.107(0.052)^{* *}$ \\
\hline Human capital (lag) & $-0.274(0.141)^{*}$ & $-0.304(0.145)^{* *}$ & $-0.279(0.141)^{* *}$ & $-0.291(0.143)^{* *}$ & $-0.272(0.141)^{*}$ & $-0.307(0.146)^{* *}$ \\
\hline Operating margin & $-0.246(0.088)^{* * *}$ & $-0.249(0.088)^{* * *}$ & $-0.246(0.089)^{* * *}$ & $-0.251(0.090)^{* * *}$ & $-0.242(0.088)^{* * *}$ & $-0.253(0.089)^{* * *}$ \\
\hline Age $(\log )$ & $-0.108(0.035)^{* * *}$ & $-0.105(0.035)^{* * *}$ & $-0.111(0.036)^{* * *}$ & $-0.111(0.036)^{* * *}$ & $-0.108(0.035)^{* * *}$ & $-0.111(0.038)^{* * *}$ \\
\hline Group member & $-0.096(0.045)^{* *}$ & $-0.101(0.045)^{* *}$ & $-0.099(0.046)^{* *}$ & $-0.101(0.047)^{* *}$ & $-0.099(0.046)^{* *}$ & $-0.111(0.048)^{* *}$ \\
\hline Company & $0.078(0.064)$ & $0.091(0.065)$ & $0.084(0.064)$ & $0.103(0.065)$ & $0.075(0.064)$ & $0.084(0.068)$ \\
\hline Foreign ownership & $-0.007(0.065)$ & $0.003(0.065)$ & $-0.003(0.066)$ & $0.003(0.067)$ & $-0.005(0.065)$ & $-0.005(0.069)$ \\
\hline Time effect CIS6 & $0.551(0.040)^{* * *}$ & $0.555(0.041)^{* * *}$ & $0.551(0.040)^{* * *}$ & $0.551(0.040)^{* * *}$ & $0.551(0.040)^{* * *}$ & $0.560(0.041)^{* * *}$ \\
\hline Time effect CIS7 & $0.445(0.077)^{* * *}$ & $0.451(0.079)^{* * *}$ & $0.446(0.078)^{* * *}$ & $0.450(0.078)^{* * *}$ & $0.446(0.077)^{* * *}$ & $0.466(0.080)^{* * *}$ \\
\hline Industry effects & Yes & Yes & Yes & Yes & Yes & Yes \\
\hline \multicolumn{7}{|l|}{ Wooldridge terms } \\
\hline R\&D in CIS4 & $0.115(0.064)^{*}$ & $0.060(0.061)$ & $0.002(0.080)$ & & $0.154(0.066)^{* *}$ & $0.124(0.065)^{*}$ \\
\hline Fin. constr. in CIS4 & $0.474(0.067)^{* * *}$ & $0.455(0.066)^{* * *}$ & $0.494(0.070)^{* * *}$ & $0.500(0.070)^{* * *}$ & $0.473(0.067)^{* * *}$ & $0.515(0.072)^{* * *}$ \\
\hline Turnover (log), CIS4 & $-0.003(0.015)$ & $-0.001(0.015)$ & $-0.003(0.015)$ & $-0.002(0.015)$ & $-0.003(0.015)$ & $-0.002(0.016)$ \\
\hline Turnover (log), CIS5 & $0.017(0.039)$ & $0.020(0.040)$ & $0.017(0.039)$ & $0.022(0.039)$ & $0.017(0.039)$ & $0.025(0.042)$ \\
\hline Turnover (log), CIS6 & $-0.069(0.030)^{* *}$ & $-0.073(0.031)^{* *}$ & $-0.070(0.031)^{* *}$ & $-0.075(0.031)^{* *}$ & $-0.067(0.030)^{* *}$ & $-0.074(0.032)^{* *}$ \\
\hline Market scope, CIS5 & $0.019(0.037)$ & $0.012(0.038)$ & $0.023(0.037)$ & $0.023(0.038)$ & $0.019(0.037)$ & $0.016(0.038)$ \\
\hline Market scope, CIS6 & $-0.095(0.044)^{* *}$ & $-0.102(0.044)^{* *}$ & $-0.089(0.044)^{* *}$ & $-0.085(0.045)^{*}$ & $-0.095(0.044)^{* *}$ & $-0.104(0.046)^{* *}$ \\
\hline Market scope, CIS7 & $-0.026(0.018)$ & $-0.028(0.018)$ & $-0.027(0.019)$ & $-0.027(0.019)$ & $-0.026(0.018)$ & $-0.030(0.019)$ \\
\hline Human capital, CIS4 & $0.059(0.127)$ & $0.050(0.128)$ & $0.083(0.129)$ & $0.086(0.130)$ & $0.055(0.126)$ & $0.064(0.130)$ \\
\hline Human capital, CIS5 & $0.248(0.120)^{* *}$ & $0.264(0.121)^{* *}$ & $0.257(0.121)^{* *}$ & $0.268(0.123)^{* *}$ & $0.249(0.120)^{* *}$ & $0.263(0.125)^{* *}$ \\
\hline Human capital, CIS6 & $0.083(0.132)$ & $0.051(0.135)$ & $0.089(0.134)$ & $0.090(0.136)$ & $0.080(0.132)$ & $0.083(0.140)$ \\
\hline Operating margin, CIS4 & $0.097(0.130)$ & $0.095(0.133)$ & $0.076(0.125)$ & $0.075(0.130)$ & $0.097(0.129)$ & $0.100(0.138)$ \\
\hline Operating margin, CIS5 & $0.113(0.124)$ & $0.117(0.125)$ & $0.125(0.126)$ & $0.137(0.128)$ & $0.111(0.124)$ & $0.108(0.131)$ \\
\hline Operating margin, CIS6 & $0.030(0.140)$ & $0.033(0.140)$ & $0.038(0.140)$ & $0.029(0.141)$ & $0.015(0.142)$ & $0.021(0.149)$ \\
\hline Error correlation i,t & $0.085(0.045)^{*}$ & $0.223(0.044)^{* * *}$ & $0.094(0.046)^{* *}$ & $0.120(0.049)^{* *}$ & $0.091(0.047)^{*}$ & $0.201(0.045)^{* * *}$ \\
\hline Error correlation $\mathrm{i}$ & $0.413(0.240)^{*}$ & $-0.175(0.347)$ & $0.442(0.226)^{*}$ & $0.506(0.208)^{* *}$ & $0.365(0.234)$ & $0.006(0.192)$ \\
\hline SD random effect eq. $\mathrm{A}$ & $0.692(0.083)^{* * *}$ & $0.712(0.079)^{* * *}$ & $0.325(0.114)^{* * *}$ & $0.540(0.100)^{* * *}$ & $0.735(0.085)^{* * *}$ & $0.760(0.081)^{* * *}$ \\
\hline SD random effect eq. $B$ & $0.266(0.025)^{* * *}$ & $0.204(0.023)^{* * *}$ & $0.289(0.028)^{* * *}$ & $0.304(0.027)^{* * *}$ & $0.270(0.026)^{* * *}$ & $0.338(0.030)^{* * *}$ \\
\hline Observations & 6995 & 6930 & 6932 & 6921 & 6995 & 6945 \\
\hline Log-Likelihood & -6643 & -6905 & -54144 & -5721 & -6517 & -6839 \\
\hline Wald statistic & 1857 & 1805 & 1474 & 1513 & 1787 & 1742 \\
\hline Wald p-value & 0.000 & 0.000 & 0.000 & 0.000 & 0.000 & 0.000 \\
\hline
\end{tabular}

Notes: This table presents results for bivariate panel probit models with six R\&D measures and a financial constraints measure as dependent variables. All models are estimated using maximum simulated likelihood with 100 random draws and standard errors (in parentheses) based on the outer product of the matrix of contributions to the gradient. Intercepts and industry effects are not shown. Wooldridge terms correspond to the coefficients in equation (3). Significance levels: $* * * \mathrm{p}<0.01, * * \mathrm{p}<0.05, * \mathrm{p}<0.1$. 
Table 4

Innovation: simultaneous equations

\begin{tabular}{|c|c|c|c|c|c|c|}
\hline $\begin{array}{l}\text { Dependent variable } \\
\text { in innovation eqn. }\end{array}$ & $\begin{array}{l}\text { Innovation } \\
\text { any }\end{array}$ & $\begin{array}{c}\text { Innovation } \\
\text { new to market }\end{array}$ & $\begin{array}{l}\text { Innovation } \\
\text { new to firm }\end{array}$ & $\begin{array}{l}\text { Innovation } \\
\text { (good) }\end{array}$ & $\begin{array}{c}\text { Innovation } \\
\text { (process) }\end{array}$ & $\begin{array}{l}\text { Innovation } \\
\text { (service) }\end{array}$ \\
\hline \multicolumn{7}{|l|}{ Dependent: Innovation } \\
\hline Innovation (lag) & $0.522(0.075)^{* * *}$ & $0.640(0.110)^{* * *}$ & $0.450(0.095)^{* * *}$ & $0.546(0.103)^{* * *}$ & $0.519(0.085)^{* * *}$ & $0.444(0.092)^{* * *}$ \\
\hline Fin. constraints (lag) & $0.007(0.073)$ & $0.058(0.098)$ & $0.011(0.079)$ & $0.003(0.085)$ & $0.076(0.082)$ & $0.041(0.080)$ \\
\hline Turnover (log) (lag) & $-0.028(0.037)$ & $-0.019(0.065)$ & $0.000(0.051)$ & $-0.039(0.046)$ & $0.017(0.040)$ & $-0.060(0.046)$ \\
\hline Market scope & $0.115(0.048)^{* *}$ & $0.130(0.070)^{*}$ & $0.009(0.062)$ & $0.044(0.062)$ & $0.089(0.057)$ & $0.068(0.054)$ \\
\hline Human capital (lag) & $-0.059(0.144)$ & $0.064(0.222)$ & $-0.068(0.170)$ & $0.005(0.178)$ & $-0.055(0.178)$ & $0.019(0.170)$ \\
\hline Market share (lag) & $0.021(0.026)$ & $-0.004(0.034)$ & $0.000(0.031)$ & $0.007(0.038)$ & $0.032(0.030)$ & $-0.025(0.029)$ \\
\hline Age $(\log )$ & $-0.036(0.039)$ & $-0.058(0.054)$ & $-0.014(0.042)$ & $-0.082(0.048)^{*}$ & $-0.040(0.046)$ & $-0.033(0.046)$ \\
\hline Group member & $-0.085(0.050)^{*}$ & $-0.089(0.066)$ & $0.003(0.053)$ & $-0.019(0.060)$ & $-0.107(0.058)^{*}$ & $-0.166(0.056)^{* * *}$ \\
\hline Company & $0.007(0.064)$ & $0.105(0.099)$ & $0.060(0.079)$ & $0.132(0.091)$ & $-0.060(0.078)$ & $0.126(0.075)^{*}$ \\
\hline Foreign ownership & $0.012(0.071)$ & $0.027(0.082)$ & $-0.005(0.074)$ & $-0.007(0.076)$ & $0.009(0.077)$ & $-0.028(0.080)$ \\
\hline Time effect CIS6 & $0.103(0.039)^{* * *}$ & $0.351(0.056)^{* * *}$ & $-0.048(0.046)$ & $0.050(0.047)$ & $0.032(0.047)$ & $-0.017(0.044)$ \\
\hline Time effect CIS7 & $0.203(0.079)^{* *}$ & $0.318(0.107)^{* * *}$ & $0.016(0.090)$ & $0.095(0.104)$ & $0.093(0.088)$ & $0.032(0.089)$ \\
\hline Industry effects & Yes & Yes & Yes & Yes & Yes & Yes \\
\hline \multicolumn{7}{|l|}{ Wooldridge terms } \\
\hline Innovation in CIS4 & $0.483(0.079)^{* * *}$ & $0.732(0.121)^{* * *}$ & $0.245(0.089)^{* * *}$ & $0.697(0.115)^{* * *}$ & $0.386(0.086)^{* * *}$ & $0.591(0.099)^{* * *}$ \\
\hline Fin. constr. in CIS4 & $0.098(0.067)$ & $-0.014(0.083)$ & $0.092(0.072)$ & $0.052(0.077)$ & $0.133(0.074)^{*}$ & $0.075(0.074)$ \\
\hline Turnover (log), CIS4 & $-0.007(0.018)$ & $0.006(0.021)$ & $-0.022(0.020)$ & $0.031(0.023)$ & $-0.007(0.019)$ & $0.016(0.023)$ \\
\hline Turnover (log), CIS5 & $0.001(0.049)$ & $-0.036(0.078)$ & $-0.006(0.060)$ & $-0.031(0.061)$ & $-0.072(0.056)$ & $-0.013(0.059)$ \\
\hline Turnover (log), CIS6 & $0.060(0.040)$ & $0.066(0.061)$ & $0.025(0.045)$ & $0.040(0.052)$ & $0.136(0.049)^{* * *}$ & $0.103(0.048)^{* *}$ \\
\hline Market scope, CIS5 & $0.077(0.040)^{*}$ & $-0.001(0.056)$ & $0.087(0.045)^{*}$ & $0.051(0.052)$ & $0.020(0.043)$ & $0.067(0.046)$ \\
\hline Market scope, CIS6 & $-0.002(0.042)$ & $0.047(0.059)$ & $0.005(0.050)$ & $0.057(0.054)$ & $0.025(0.052)$ & $-0.002(0.046)$ \\
\hline Market scope, CIS7 & $0.013(0.026)$ & $0.031(0.032)$ & $0.003(0.028)$ & $0.044(0.030)$ & $0.009(0.029)$ & $0.003(0.029)$ \\
\hline Human capital, CIS4 & $0.095(0.143)$ & $0.023(0.178)$ & $0.208(0.157)$ & $0.194(0.173)$ & $-0.038(0.158)$ & $0.068(0.159)$ \\
\hline Human capital, CIS5 & $-0.019(0.126)$ & $-0.088(0.196)$ & $-0.103(0.142)$ & $-0.062(0.149)$ & $0.164(0.149)$ & $-0.063(0.146)$ \\
\hline Human capital, CIS6 & $0.376(0.143)^{* * *}$ & $0.522(0.184)^{* * *}$ & $0.071(0.155)$ & $0.218(0.170)$ & $0.216(0.163)$ & $0.490(0.157)^{* * *}$ \\
\hline Market share, CIS4 & $0.031(0.031)$ & $0.050(0.042)$ & $0.022(0.035)$ & $0.044(0.043)$ & $0.057(0.037)$ & $0.038(0.035)$ \\
\hline Market share, CIS5 & $-0.015(0.030)$ & $-0.004(0.039)$ & $0.014(0.032)$ & $-0.003(0.037)$ & $-0.072(0.039)^{*}$ & $-0.003(0.033)$ \\
\hline Market share, CIS6 & $0.027(0.012)^{* *}$ & $0.040(0.017)^{* *}$ & $0.011(0.013)$ & $0.047(0.015)^{* * *}$ & $0.014(0.014)$ & $0.027(0.013)^{* *}$ \\
\hline \multicolumn{7}{|c|}{ Dependent: Financial constraints } \\
\hline Innovation (lag) & $0.051(0.069)$ & $0.202(0.092)^{* *}$ & $-0.042(0.083)$ & $0.060(0.086)$ & $0.128(0.075)^{*}$ & $0.063(0.076)$ \\
\hline Fin. constraints (lag) & $0.500(0.069)^{* * *}$ & $0.459(0.075)^{* * *}$ & $0.473(0.075)^{* * *}$ & $0.484(0.073)^{* * *}$ & $0.512(0.067)^{* * *}$ & $0.498(0.066)^{* * *}$ \\
\hline Turnover (log) (lag) & $0.052(0.037)$ & $0.047(0.037)$ & $0.046(0.038)$ & $0.050(0.038)$ & $0.052(0.037)$ & $0.057(0.037)$ \\
\hline Market scope & $0.110(0.050)^{* *}$ & $0.105(0.050)^{* *}$ & $0.108(0.051)^{* *}$ & $0.110(0.051)^{* *}$ & $0.105(0.050)^{* *}$ & $0.111(0.051)^{* *}$ \\
\hline Human capital (lag) & $-0.270(0.142)^{*}$ & $-0.281(0.141)^{* *}$ & $-0.276(0.142)^{*}$ & $-0.263(0.141)^{*}$ & $-0.276(0.141)^{* *}$ & $-0.270(0.143)^{*}$ \\
\hline Operating margin & $-0.234(0.089)^{* * *}$ & $-0.244(0.090)^{* * *}$ & $-0.241(0.089)^{* * *}$ & $-0.245(0.088)^{* * *}$ & $-0.231(0.087)^{* * *}$ & $-0.237(0.087)^{* * *}$ \\
\hline Age (log) & $-0.102(0.035)^{* * *}$ & $-0.107(0.036)^{* * *}$ & $-0.113(0.037)^{* * *}$ & $-0.106(0.036)^{* * *}$ & $-0.108(0.035)^{* * *}$ & $-0.110(0.035)^{* * *}$ \\
\hline Group member & $-0.101(0.045)^{* *}$ & $-0.105(0.046)^{* *}$ & $-0.104(0.047)^{* *}$ & $-0.106(0.046)^{* *}$ & $-0.095(0.045)^{* *}$ & $-0.097(0.045)^{* *}$ \\
\hline Company & $0.097(0.064)$ & $0.102(0.066)$ & $0.103(0.067)$ & $0.087(0.065)$ & $0.093(0.063)$ & $0.087(0.064)$ \\
\hline Foreign ownership & $0.002(0.065)$ & $0.008(0.067)$ & $-0.003(0.067)$ & $-0.001(0.066)$ & $0.000(0.064)$ & $0.000(0.065)$ \\
\hline Time effect CIS6 & $0.554(0.040)^{* * *}$ & $0.569(0.041)^{* * *}$ & $0.560(0.040)^{* * *}$ & $0.557(0.040)^{* * *}$ & $0.555(0.040)^{* * *}$ & $0.549(0.039)^{* * *}$ \\
\hline Time effect CIS7 & $0.451(0.078)^{* * *}$ & $0.460(0.079)^{* * *}$ & $0.457(0.079)^{* * *}$ & $0.448(0.079)^{* * *}$ & $0.450(0.078)^{* * *}$ & $0.446(0.077)^{* * *}$ \\
\hline Industry effects & Yes & Yes & Yes & Yes & Yes & Yes \\
\hline \multicolumn{7}{|l|}{ Wooldridge terms } \\
\hline Innovation in CIS4 & $0.090(0.057)$ & $0.017(0.076)$ & $0.033(0.071)$ & $0.118(0.073)$ & $0.027(0.060)$ & $0.056(0.066)$ \\
\hline Fin. constr. in CIS4 & $0.460(0.065)^{* * *}$ & $0.497(0.073)^{* * *}$ & $0.499(0.073)^{* * *}$ & $0.485(0.071)^{* * *}$ & $0.455(0.066)^{* * *}$ & $0.466(0.065)^{* * *}$ \\
\hline Turnover (log), CIS4 & $-0.006(0.015)$ & $-0.006(0.015)$ & $-0.007(0.015)$ & $-0.005(0.015)$ & $-0.005(0.015)$ & $-0.002(0.015)$ \\
\hline Turnover (log), CIS5 & $0.017(0.038)$ & $0.018(0.039)$ & $0.020(0.040)$ & $0.021(0.039)$ & $0.018(0.039)$ & $0.016(0.038)$ \\
\hline Turnover (log), CIS6 & $-0.072(0.030)^{* *}$ & $-0.064(0.031)^{* *}$ & $-0.062(0.031)^{* *}$ & $-0.072(0.031)^{* *}$ & $-0.074(0.030)^{* *}$ & $-0.073(0.030)^{* *}$ \\
\hline Market scope, CIS5 & $0.014(0.037)$ & $0.019(0.038)$ & $0.025(0.038)$ & $0.017(0.037)$ & $0.017(0.036)$ & $0.017(0.037)$ \\
\hline Market scope, CIS6 & $-0.091(0.044)^{* *}$ & $-0.096(0.044)^{* *}$ & $-0.089(0.045)^{* *}$ & $-0.096(0.044)^{* *}$ & $-0.085(0.043)^{*}$ & $-0.090(0.044)^{* *}$ \\
\hline Market scope, CIS7 & $-0.028(0.018)$ & $-0.030(0.019)$ & $-0.031(0.019)^{*}$ & $-0.027(0.019)$ & $-0.028(0.018)$ & $-0.029(0.018)$ \\
\hline Human capital, CIS4 & $0.057(0.125)$ & $0.068(0.129)$ & $0.081(0.129)$ & $0.079(0.127)$ & $0.075(0.124)$ & $0.071(0.125)$ \\
\hline Human capital, CIS5 & $0.244(0.119)^{* *}$ & $0.249(0.121)^{* *}$ & $0.256(0.122)^{* *}$ & $0.239(0.120)^{* *}$ & $0.253(0.118)^{* *}$ & $0.248(0.119)^{* *}$ \\
\hline Human capital, CIS6 & $0.086(0.130)$ & $0.040(0.136)$ & $0.059(0.137)$ & $0.088(0.132)$ & $0.079(0.129)$ & $0.074(0.132)$ \\
\hline Operating margin, CIS4 & $0.088(0.136)$ & $0.106(0.142)$ & $0.090(0.126)$ & $0.096(0.138)$ & $0.084(0.130)$ & $0.089(0.133)$ \\
\hline Operating margin, CIS5 & $0.101(0.123)$ & $0.125(0.129)$ & $0.125(0.127)$ & $0.111(0.122)$ & $0.114(0.123)$ & $0.102(0.120)$ \\
\hline Operating margin, CIS6 & $-0.008(0.141)$ & $0.014(0.146)$ & $0.015(0.144)$ & $0.006(0.147)$ & $0.004(0.140)$ & $0.000(0.141)$ \\
\hline Error correlation i,t & $0.145(0.041)^{* * *}$ & $0.079(0.052)$ & $0.149(0.043)^{* * *}$ & $0.161(0.048)^{* * *}$ & $0.141(0.045)^{* * *}$ & $0.119(0.045)^{* * *}$ \\
\hline Error correlation $\mathrm{i}$ & $0.461(0.303)$ & $0.138(0.297)$ & $0.150(0.329)$ & $0.249(0.316)$ & $0.250(0.373)$ & $0.512(0.345)$ \\
\hline SD random effect eq. A & $0.510(0.077)^{* * *}$ & $0.504(0.110)^{* * *}$ & $0.334(0.101)^{* * *}$ & $-0.497(0.101)^{* * *}$ & $0.538(0.087)^{* * *}$ & $-0.540(0.085)^{* * *}$ \\
\hline SD random effect eq. B & $0.238(0.024)^{* * *}$ & $0.309(0.030)^{* * *}$ & $0.313(0.030)^{* * *}$ & $0.283(0.029)^{* * *}$ & $0.211(0.023)^{* * *}$ & $0.249(0.024)^{* * *}$ \\
\hline Observations & 6973 & 6910 & 6906 & 6982 & 6986 & 6975 \\
\hline Log-Likelihood & -7100 & -5353 & -5911 & -5926 & -6195 & -6354 \\
\hline Wald statistic & 1863 & 1421 & 1003 & 1846 & 1435 & 1439 \\
\hline Wald p-value & 0.000 & 0.000 & 0.000 & 0.000 & 0.000 & 0.000 \\
\hline
\end{tabular}

Notes: This table presents results for bivariate panel probit models with six innovation measures and a financial constraints measure as dependent variables. All models are estimated using maximum simulated likelihood with 100 random draws and standard errors (in parentheses) based on the outer product of the matrix of contributions to the gradient. Intercepts and industry effects are not shown. Wooldridge terms correspond to the coefficients in equation (3). Significance levels: ${ }^{* * *} \mathrm{p}<0.01,{ }^{* *} \mathrm{p}<0.05,{ }^{*} \mathrm{p}<0.1$. 
Table 5

Financial constraints predict firm death

\begin{tabular}{|c|c|c|c|c|}
\hline & 1 & 2 & 3 & 4 \\
\hline Fin. constraints (lag) & $0.266(0.065)^{* * *}$ & $0.294(0.065)^{* * *}$ & $0.290(0.065)^{* * *}$ & $0.288(0.065)^{* * *}$ \\
\hline R\&D any (activity) & & $-0.205(0.074)^{* *}$ & & \\
\hline $\mathrm{R} \& \mathrm{D}$ any (expenditure) & & & $-0.203(0.081)^{*}$ & \\
\hline Innovation (any) & & & & $-0.158(0.073)^{*}$ \\
\hline Turnover (log) (lag) & $-0.160(0.030)^{* * *}$ & $-0.155(0.030)^{* * *}$ & $-0.156(0.030)^{* * *}$ & $-0.157(0.030)^{* * *}$ \\
\hline Market scope & $-0.058(0.033)$ & $-0.041(0.034)$ & $-0.042(0.034)$ & $-0.049(0.033)$ \\
\hline Human capital (lag) & $-0.033(0.139)$ & $0.013(0.138)$ & $-0.001(0.138)$ & $-0.020(0.138)$ \\
\hline Market share (lag) & $0.051(0.258)$ & $0.054(0.257)$ & $0.050(0.258)$ & $0.059(0.257)$ \\
\hline Operating margin & $-0.011(0.023)$ & $-0.010(0.023)$ & $-0.010(0.023)$ & $-0.011(0.023)$ \\
\hline Age $(\log )$ & $-0.292(0.053)^{* * *}$ & $-0.294(0.053)^{* * *}$ & $-0.294(0.053)^{* * *}$ & $-0.294(0.054)^{* * *}$ \\
\hline Group member & $0.012(0.074)$ & $0.011(0.074)$ & $0.013(0.074)$ & $0.007(0.074)$ \\
\hline Company & $-0.005(0.085)$ & $-0.007(0.085)$ & $-0.005(0.085)$ & $-0.010(0.085)$ \\
\hline Foreign ownership & $0.079(0.129)$ & $0.071(0.130)$ & $0.069(0.130)$ & $0.083(0.130)$ \\
\hline Time effect CIS6 & $0.027(0.063)$ & $0.032(0.063)$ & $0.028(0.063)$ & $0.026(0.063)$ \\
\hline Time effect CIS7 & $-0.184(0.180)$ & $-0.209(0.181)$ & $-0.203(0.181)$ & $-0.190(0.181)$ \\
\hline Industry effects & Yes & Yes & Yes & Yes \\
\hline Observations & 9978 & 9978 & 9978 & 9978 \\
\hline McFadden Pseudo-R² (adj.) & 0.072 & 0.075 & 0.075 & 0.074 \\
\hline Log-Likelihood & -990.646 & -986.678 & -987.348 & -988.185 \\
\hline
\end{tabular}

Notes: This table presents pooled probit regressions predicting whether a firm exits the Business Structure Database. Standard errors are shown in parentheses. Significance levels: $* * * p<0.01$, $* * \mathrm{p}<0.05, * \mathrm{p}<0.1$. 
Table 6

Research and development: panel probit models

\begin{tabular}{|c|c|c|c|c|c|c|c|}
\hline Model & $\begin{array}{c}\mathrm{R} \& \mathrm{D} \text { any } \\
\text { (expenditure) }\end{array}$ & $\begin{array}{l}\text { R\&D any } \\
\text { (activity) }\end{array}$ & $\begin{array}{l}\text { R\&D external } \\
\text { (expenditure) }\end{array}$ & $\begin{array}{l}\text { R\&D external } \\
\text { (activity) }\end{array}$ & $\begin{array}{l}\text { R\&D internal } \\
\text { (expenditure) }\end{array}$ & $\begin{array}{c}\text { R\&D internal } \\
\text { (activity) }\end{array}$ & $\begin{array}{c}\text { Financial } \\
\text { constraints }\end{array}$ \\
\hline R\&D any (expend.) (lag) & $1.071(0.038)^{* * *}$ & & & & & & $0.171(0.040)^{* * *}$ \\
\hline R\&D any (activity) (lag) & & $1.030(0.037)^{* * *}$ & & & & & \\
\hline R\&D external (expend.) (lag) & & & $1.015(0.054)^{* * *}$ & & & & \\
\hline R\&D internal (expend.) (lag) & & & & & $1.103(0.039)^{* * *}$ & & \\
\hline R\&D internal (activity) (lag) & & & & & & $1.052(0.037)^{* * *}$ & \\
\hline Fin. constraints (lag) & $0.087(0.043)^{* *}$ & $0.056(0.042)$ & $-0.002(0.053)$ & $-0.002(0.049)$ & $0.097(0.044)^{* *}$ & $0.081(0.042)^{*}$ & $0.802(0.039)^{* * *}$ \\
\hline Turnover (log) (lag) & $0.033(0.015)^{* *}$ & $0.021(0.015)$ & $0.040(0.019)^{* *}$ & $0.056(0.018)^{* * *}$ & $0.026(0.016)$ & $0.016(0.015)$ & $-0.002(0.012)$ \\
\hline Operating margin & & & & & & & $-0.441(0.141)^{* * *}$ \\
\hline Age $(\log )$ & $-0.018(0.034)$ & $-0.024(0.032)$ & $-0.040(0.043)$ & $-0.074(0.039)^{*}$ & $-0.021 \quad(0.035)$ & $-0.021(0.033)$ & $-0.129(0.032)^{* * *}$ \\
\hline Group member & $-0.019(0.042)$ & $-0.024(0.041)$ & $0.087(0.052)^{*}$ & $0.044(0.048)$ & $-0.040(0.043)$ & $-0.046(0.041)$ & $-0.106(0.042)^{* *}$ \\
\hline Company & $0.089(0.062)$ & $0.035(0.057)$ & $0.042(0.084)$ & $-0.022(0.075)$ & $0.102(0.063)$ & $0.038(0.058)$ & $0.001(0.058)$ \\
\hline Foreign ownership & $-0.194(0.059)^{* * *}$ & $-0.091(0.058)$ & $-0.064(0.067)$ & $0.013(0.063)$ & $-0.187(0.060)^{* * *}$ & $-0.111(0.058)^{*}$ & $-0.011(0.059)$ \\
\hline Time effect CIS6 & $0.082(0.037)^{* *}$ & $0.106(0.036)^{* * *}$ & $-0.100(0.047)^{* *}$ & $-0.024(0.043)$ & $0.083(0.038)^{* *}$ & $0.113(0.036)^{* * *}$ & $0.537(0.037)^{* * *}$ \\
\hline Time effect CIS7 & $-0.180(0.067)^{* * *}$ & $-0.292(0.065)^{* * *}$ & $-0.183(0.080)^{* *}$ & $-0.170(0.076)^{* *}$ & $-0.196(0.069)^{* * *}$ & $-0.297(0.066)^{* * *}$ & $0.339(0.066)^{* * *}$ \\
\hline Chi-sq. test & 1769 & 1804 & 697 & 834 & 1786 & 1807 & 721 \\
\hline P-value & 0.000 & 0.000 & 0.000 & 0.000 & 0.000 & 0.000 & 0.000 \\
\hline
\end{tabular}

Notes: This table presents random effects probit models for six R\&D measures and financial constraints as dependent variables. Heteroskedasticity-robust

Notes: This table presents random effects probit models for six R\&D measures and fina
standard errors are in parentheses. Significance levels: ${ }^{* * *} \mathrm{p}<0.01,{ }^{* *} \mathrm{p}<0.05,{ }^{*} \mathrm{p}<0.1$. 
Table 7

Innovation: panel probit models

\begin{tabular}{|c|c|c|c|c|c|c|c|}
\hline Model & $\begin{array}{c}\text { Innovation } \\
\text { any }\end{array}$ & $\begin{array}{c}\text { Innovation } \\
\text { new to market }\end{array}$ & $\begin{array}{l}\text { Innovation } \\
\text { new to firm }\end{array}$ & $\begin{array}{c}\begin{array}{c}\text { Innovation } \\
\text { (good) }\end{array} \\
\end{array}$ & $\begin{array}{c}\begin{array}{c}\text { Innovation } \\
\text { (process) }\end{array} \\
\end{array}$ & $\begin{array}{c}\begin{array}{c}\text { Innovation } \\
\text { (service) }\end{array} \\
\end{array}$ & $\begin{array}{c}\text { Financial } \\
\text { constraints }\end{array}$ \\
\hline Innovation (any) (lag) & $0.910(0.035)^{* * *}$ & & & & & & $0.147(0.038)^{* * *}$ \\
\hline Innovation new to market (lag) & & $1.194(0.053)^{* * *}$ & & & & & \\
\hline Innovation new to firm (lag) & & & $0.648(0.063)^{* * *}$ & & & & \\
\hline Innovation (process) (lag) & & & & & $0.826(0.052)^{* * *}$ & & \\
\hline Innovation (service) (lag) & & & & & & $0.909(0.043)^{* * *}$ & \\
\hline Fin. constraints (lag) & $0.106(0.041)^{* * *}$ & $0.082(0.052)$ & $0.087(0.047)^{*}$ & $0.059(0.047)$ & $0.159(0.047)^{* * *}$ & $0.129(0.044)^{* * *}$ & $0.795(0.040)^{* * *}$ \\
\hline Turnover (log) (lag) & $0.007(0.015)$ & $0.006(0.019)$ & $0.000(0.017)$ & $-0.007(0.017)$ & $0.047(0.017)^{* * *}$ & 0.015 & $-0.001(0.012)$ \\
\hline Market share (lag) & $0.043(0.012)^{* * *}$ & $0.038(0.016)^{* *}$ & $0.030(0.014)^{* *}$ & $0.043(0.014)^{* * *}$ & $0.032(0.014)^{* *}$ & $0.017(0.013)$ & \\
\hline Operating margin & & & & & & & $-0.447(0.142)^{* * *}$ \\
\hline Age $(\log )$ & $-0.055(0.032)^{*}$ & $-0.062(0.043)$ & $-0.026(0.038)$ & $-0.090(0.038)^{* *}$ & $-0.051(0.038)$ & $-0.046(0.035)$ & $-0.122(0.032)^{* * *}$ \\
\hline Group member & $-0.040(0.040)$ & $-0.041(0.053)$ & $0.011(0.048)$ & $0.013(0.048)$ & $-0.073(0.048)$ & $-0.103(0.044)^{* *}$ & $-0.107(0.042)^{* *}$ \\
\hline Company & $-0.018(0.056)$ & $0.074(0.084)$ & $0.044(0.069)$ & $0.080(0.076)$ & $-0.068(0.069)$ & $0.088(0.062)$ & $0.014(0.058)$ \\
\hline Foreign ownership & $0.019(0.056)$ & $0.023(0.068)$ & $0.007(0.065)$ & $0.001(0.063)$ & $0.020(0.064)$ & $-0.003(0.062)$ & $-0.017(0.060)$ \\
\hline Time effect CIS6 & $0.109(0.036)^{* * *}$ & $0.351(0.049)^{* * *}$ & $-0.051(0.042)$ & $0.035(0.042)$ & $0.037(0.042)$ & $-0.040(0.039)$ & $0.541(0.037)^{* * *}$ \\
\hline Time effect CIS7 & $0.129(0.062)^{* *}$ & $0.230(0.081)^{* * *}$ & $-0.025(0.074)$ & $-0.018(0.075)$ & $0.059(0.071)$ & $-0.065(0.068)$ & $0.349(0.066)^{* * *}$ \\
\hline Chi-sq. test & 1386 & 1019 & 251 & 1515 & 817 & 757 & 715 \\
\hline P-value & 0.000 & 0.000 & 0.000 & 0.000 & 0.000 & 0.000 & 0.000 \\
\hline
\end{tabular}

Notes: This table presents random effects probit models for six innovation measures and financial constraints as dependent variables. Heteroskedasticity-

robust standard errors are in parentheses. Significance levels: *** $\mathrm{p}<0.01, * * \mathrm{p}<0.05,{ }^{*} \mathrm{p}<0.1$. 
Table 8

Research and development: simultaneous equations (Mundlak estimator)

\begin{tabular}{|c|c|c|c|c|c|c|}
\hline Model & $\begin{array}{c}\text { R\&D any } \\
\text { (expenditure) }\end{array}$ & $\begin{array}{l}\text { R\&D any } \\
\text { (activity) }\end{array}$ & $\begin{array}{c}\text { R\&D external } \\
\text { (expenditure) }\end{array}$ & $\begin{array}{c}\text { R\&D external } \\
\text { (activity) }\end{array}$ & $\begin{array}{l}\text { R\&D internal } \\
\text { (expenditure) }\end{array}$ & $\begin{array}{c}\text { R\&D internal } \\
\text { (activity) }\end{array}$ \\
\hline \multicolumn{7}{|l|}{ Dependent: $R \& D$} \\
\hline R\&D (lag) & $0.404(0.089)^{* * *}$ & $0.373(0.086)^{* * *}$ & $0.604(0.104)^{* * *}$ & $0.405(0.110)^{* * *}$ & $0.403(0.092)^{* * *}$ & $0.372(0.089)^{* * *}$ \\
\hline Fin. constraints (lag) & $-0.069(0.085)$ & $0.034(0.081)$ & $-0.136(0.086)$ & $-0.188(0.088)^{* *}$ & $-0.039(0.089)$ & $0.033(0.084)$ \\
\hline Turnover (log) (lag) & $-0.073(0.047)$ & $-0.111(0.041)^{* * *}$ & $-0.036(0.056)$ & $-0.008(0.053)$ & $-0.079(0.049)$ & $-0.128(0.042)^{* * *}$ \\
\hline Market scope & $0.005(0.055)$ & $0.045(0.047)$ & $0.019(0.074)$ & $0.049(0.064)$ & $-0.008(0.057)$ & $0.051(0.049)$ \\
\hline Human capital (lag) & $-0.115(0.158)$ & $-0.127(0.150)$ & $-0.245(0.194)$ & $-0.172(0.182)$ & $-0.072(0.161)$ & $-0.132(0.149)$ \\
\hline Market share (lag) & $0.002(0.032)$ & $0.039(0.028)$ & $0.053(0.043)$ & $0.049(0.039)$ & $-0.003(0.033)$ & $0.022(0.028)$ \\
\hline Age $(\log )$ & $-0.005(0.046)$ & $-0.013(0.045)$ & $-0.034(0.048)$ & $-0.070(0.049)$ & $-0.015(0.048)$ & $-0.011(0.047)$ \\
\hline Group member & $-0.042(0.057)$ & $-0.054(0.056)$ & $0.050(0.058)$ & $0.010(0.062)$ & $-0.072(0.060)$ & $-0.081(0.059)$ \\
\hline Company & $0.101(0.083)$ & $0.044(0.078)$ & $0.049(0.090)$ & $-0.009(0.090)$ & $0.103(0.087)$ & $0.019(0.081)$ \\
\hline Foreign ownership & $-0.317(0.080)^{* * *}$ & $-0.164(0.079)^{* *}$ & $-0.062(0.076)$ & $0.018(0.081)$ & $-0.301(0.083)^{* * *}$ & $-0.198(0.081)^{* *}$ \\
\hline Time effect CIS6 & $0.119(0.042)^{* * *}$ & $0.173(0.041)^{* * *}$ & $-0.066(0.051)$ & $-0.001(0.048)$ & $0.123(0.044)^{* * *}$ & $0.185(0.042)^{* * *}$ \\
\hline Time effect CIS7 & $-0.140(0.084)^{*}$ & $-0.237(0.079)^{* * *}$ & $-0.107(0.096)$ & $-0.097(0.097)$ & $-0.163(0.089)^{*}$ & $-0.246(0.084)^{* * *}$ \\
\hline Industry effects & Yes & Yes & Yes & Yes & Yes & Yes \\
\hline \multicolumn{7}{|l|}{ Mundlak terms } \\
\hline R\&D in CIS4 & $0.868(0.105)^{* * *}$ & $0.817(0.099)^{* * *}$ & $0.599(0.113)^{* * *}$ & $0.762(0.120)^{* * *}$ & $0.909(0.111)^{* * *}$ & $0.852(0.105)^{* * *}$ \\
\hline Fin. constr. in CIS4 & $0.163(0.076)^{* *}$ & $0.094(0.074)$ & $0.112(0.077)$ & $0.191(0.081)^{* *}$ & $0.140(0.079)^{*}$ & $0.108(0.075)$ \\
\hline Turnover (log) (lag), avg. & $0.126(0.053)^{* *}$ & $0.164(0.048)^{* * *}$ & $0.085(0.061)$ & $0.086(0.057)$ & $0.122(0.055)^{* *}$ & $0.173(0.049)^{* * *}$ \\
\hline Market scope, avg. & $0.256(0.063)^{* * *}$ & $0.208(0.056)^{* * *}$ & $0.130(0.081)$ & $0.122(0.073)^{*}$ & $0.292(0.066)^{* * *}$ & $0.222(0.059) * * *$ \\
\hline Human capital (lag), avg. & $0.789(0.218)^{* * *}$ & $0.778(0.214)^{* * *}$ & $0.577(0.249)^{* *}$ & $0.516(0.242)^{* *}$ & $0.694(0.225)^{* * *}$ & $0.776(0.213)^{* * *}$ \\
\hline Market share (lag), avg. & $0.042(0.038)$ & $0.009(0.034)$ & $0.005(0.048)$ & $-0.003(0.046)$ & $0.050(0.039)$ & $0.026(0.035)$ \\
\hline \multicolumn{7}{|c|}{ Dependent: Financial constraints } \\
\hline R\&D (lag) & $0.048(0.075)$ & $0.206(0.076)^{* * *}$ & $0.142(0.086)$ & $0.089(0.085)$ & $0.018(0.077)$ & $0.140(0.076)^{*}$ \\
\hline Fin. constraints (lag) & $0.488(0.069)^{* * *}$ & $0.522(0.067)^{* * *}$ & $0.474(0.072)^{* * *}$ & $0.474(0.072)^{* * *}$ & $0.489(0.069)^{* * *}$ & $0.439(0.075)^{* * *}$ \\
\hline Turnover (log) (lag) & $0.058(0.040)$ & $0.056(0.040)$ & $0.058(0.040)$ & $0.060(0.041)$ & $0.058(0.040)$ & $0.057(0.041)$ \\
\hline Market scope & $0.056(0.050)$ & $0.059(0.051)$ & $0.058(0.050)$ & $0.052(0.051)$ & $0.056(0.050)$ & $0.059(0.051)$ \\
\hline Human capital (lag) & $-0.233(0.135)^{*}$ & $-0.263(0.138)^{*}$ & $-0.242(0.135)^{*}$ & $-0.254(0.137)^{*}$ & $-0.230(0.134)^{*}$ & $-0.273(0.140)^{*}$ \\
\hline Operating margin & $-0.210(0.085)^{* *}$ & $-0.213(0.085)^{* *}$ & $-0.209(0.085)^{* *}$ & $-0.208(0.085)^{* *}$ & $-0.203(0.085)^{* *}$ & $-0.217(0.087)^{* *}$ \\
\hline Age $(\log )$ & $-0.104(0.035)^{* * *}$ & $-0.100(0.035)^{* * *}$ & $-0.108(0.035)^{* * *}$ & $-0.108(0.036)^{* * *}$ & $-0.104(0.035)^{* * *}$ & $-0.107(0.037)^{* * *}$ \\
\hline Group member & $-0.100(0.045)^{* *}$ & $-0.104(0.045)^{* *}$ & $-0.103(0.046)^{* *}$ & $-0.105(0.047)^{* *}$ & $-0.103(0.045)^{* *}$ & $-0.117(0.048)^{* *}$ \\
\hline Company & $0.074(0.063)$ & $0.087(0.064)$ & $0.078(0.064)$ & $0.096(0.065)$ & $0.070(0.063)$ & $0.079(0.068)$ \\
\hline Foreign ownership & $-0.008(0.065)$ & $0.000(0.065)$ & $-0.006(0.065)$ & $0.001(0.066)$ & $-0.006(0.065)$ & $-0.008(0.069)$ \\
\hline Time effect CIS6 & $0.546(0.039)^{* * *}$ & $0.549(0.041)^{* * *}$ & $0.547(0.039)^{* * *}$ & $0.547(0.040)^{* * *}$ & $0.545(0.039)^{* * *}$ & $0.555(0.041)^{* * *}$ \\
\hline Time effect CIS7 & $0.395(0.071)^{* * *}$ & $0.396(0.072)^{* * *}$ & $0.399(0.071)^{* * *}$ & $0.406(0.072)^{* * *}$ & $0.395(0.071)^{* * *}$ & $0.413(0.073)^{* * *}$ \\
\hline Industry effects & Yes & Yes & Yes & Yes & Yes & Yes \\
\hline \multicolumn{7}{|l|}{ Mundlak terms } \\
\hline R\&D in CIS4 & $0.112(0.063)^{*}$ & $0.054(0.061)$ & $-0.003(0.080)$ & $0.001(0.075)$ & $0.152(0.065)^{* *}$ & $0.124(0.064)^{*}$ \\
\hline Fin. constr. in CIS4 & $0.470(0.067)^{* * *}$ & $0.450(0.066)^{* * *}$ & $0.493(0.071)^{* * *}$ & $0.499(0.071)^{* * *}$ & $0.468(0.067)^{* * *}$ & $0.519(0.073)^{* * *}$ \\
\hline Turnover (log) (lag), avg. & $-0.071(0.042)^{*}$ & $-0.072(0.042)^{*}$ & $-0.070(0.042)^{*}$ & $-0.072(0.043)^{*}$ & $-0.070(0.042)^{*}$ & $-0.069(0.043)$ \\
\hline Market scope, avg. & $-0.031(0.055)$ & $-0.042(0.056)$ & $-0.021(0.055)$ & $-0.017(0.056)$ & $-0.031(0.055)$ & $-0.041(0.057)$ \\
\hline Human capital (lag), avg. & $0.375(0.182)^{* *}$ & $0.358(0.185)^{*}$ & $0.418(0.184)^{* *}$ & $0.434(0.186)^{* *}$ & $0.369(0.183)^{* *}$ & $0.406(0.191)^{* *}$ \\
\hline Operating margin, avg. & $0.194(0.199)$ & $0.199(0.203)$ & $0.187(0.195)$ & $0.188(0.198)$ & $0.174(0.196)$ & $0.184(0.211)$ \\
\hline Error correlation i,t & $0.083(0.044)^{*}$ & $0.221(0.044)^{* * *}$ & $0.093(0.045)^{* *}$ & $0.125(0.050)^{* *}$ & $0.087(0.046)^{*}$ & $0.194(0.045)^{* * *}$ \\
\hline Error correlation i & $0.399(0.236)^{*}$ & $-0.171(0.337)$ & $0.419(0.218)^{*}$ & $0.456(0.207)^{* *}$ & $0.361(0.233)$ & $0.025(0.184)$ \\
\hline SD random effect eq. $A$ & $0.675(0.083)^{* * *}$ & $0.710(0.079)^{* * *}$ & $0.313(0.116)^{* * *}$ & $0.558(0.099)^{* * *}$ & $0.714(0.085)^{* * *}$ & $0.757(0.081)^{* * *}$ \\
\hline SD random effect eq. $B$ & $0.271(0.026)^{* * *}$ & $0.209(0.023)^{* * *}$ & $0.299(0.028)^{* * *}$ & $0.312(0.028)^{* * *}$ & $0.273(0.026)^{* * *}$ & $0.356(0.030)^{* * *}$ \\
\hline Observations & 6995 & 6930 & 6932 & 6921 & 6995 & 6945 \\
\hline Log-Likelihood & -6661 & -6921 & -5428 & -5738 & -6537 & -6856 \\
\hline Wald statistic & 1861 & 1799 & 1463 & 1454 & 1799 & 1732 \\
\hline Wald p-value & 0.000 & 0.000 & 0.000 & 0.000 & 0.000 & 0.000 \\
\hline
\end{tabular}

Notes: This table presents results for bivariate panel probit models with six R\&D measures and a financial constraints measure as dependent variables. All models are estimated using maximum simulated likelihood with 100 random draws and standard errors (in parentheses) based on the outer product of the matrix of contributions to the gradient. Intercepts and industry effects are not shown. All specifications in this table use Mundlak (1978) time averages rather than Wooldridge terms for the random effect's conditional mean. Significance levels: $* * * \mathrm{p}<0.01, * * \mathrm{p}<0.05, * \mathrm{p}<0.1$. 
Table 9

Innovation: simultaneous equations (Mundlak estimator)

\begin{tabular}{|c|c|c|c|c|c|c|}
\hline Model & $\begin{array}{c}\text { Innovation } \\
\text { any }\end{array}$ & $\begin{array}{c}\text { Innovation } \\
\text { new to market }\end{array}$ & $\begin{array}{l}\text { Innovation } \\
\text { new to firm }\end{array}$ & $\begin{array}{c}\text { Innovation } \\
\text { (good) }\end{array}$ & $\begin{array}{c}\text { Innovation } \\
\text { (process) }\end{array}$ & $\begin{array}{c}\text { Innovation } \\
\text { (service) }\end{array}$ \\
\hline \multicolumn{7}{|l|}{ Dependent: Innovation } \\
\hline Innovation (lag) & $0.519(0.075)^{* * *}$ & $0.636(0.110)^{* * *}$ & $0.453(0.093)^{* * *}$ & $0.600(0.097)^{* * *}$ & $0.523(0.084)^{* * *}$ & $0.518(0.088)^{* * *}$ \\
\hline Fin. constraints (lag) & $0.004(0.073)$ & $0.055(0.097)$ & $0.012(0.079)$ & $0.075(0.084)$ & $0.054(0.082)$ & $-0.015(0.073)$ \\
\hline Turnover (log) (lag) & $-0.017(0.039)$ & $-0.005(0.067)$ & $0.005(0.054)$ & $-0.032(0.050)$ & $0.019(0.040)$ & $-0.041(0.048)$ \\
\hline Market scope & $0.094(0.049)^{*}$ & $0.098(0.073)$ & $-0.005(0.062)$ & $0.022(0.061)$ & $0.084(0.056)$ & $0.027(0.053)$ \\
\hline Human capital (lag) & $-0.121(0.141)$ & $-0.072(0.207)$ & $-0.043(0.162)$ & $-0.011(0.171)$ & $-0.081(0.166)$ & $-0.068(0.160)$ \\
\hline Market share (lag) & $0.016(0.028)$ & $0.008(0.036)$ & $-0.010(0.032)$ & $0.000(0.037)$ & $0.015(0.031)$ & $-0.020(0.029)$ \\
\hline Age $(\log )$ & $-0.042(0.039)$ & $-0.065(0.054)$ & $-0.018(0.042)$ & $-0.081(0.046)^{*}$ & $-0.047(0.046)$ & $-0.035(0.044)$ \\
\hline Group member & $-0.083(0.050)^{*}$ & $-0.081(0.067)$ & $0.006(0.053)$ & $-0.004(0.057)$ & $-0.104(0.057)^{*}$ & $-0.149(0.054)^{* * *}$ \\
\hline Company & $-0.011(0.064)$ & $0.085(0.098)$ & $0.049(0.078)$ & $0.099(0.087)$ & $-0.072(0.077)$ & $0.109(0.071)$ \\
\hline Foreign ownership & $0.019(0.070)$ & $0.030(0.082)$ & $-0.007(0.074)$ & $-0.011(0.072)$ & $0.017(0.077)$ & $-0.024(0.074)$ \\
\hline Time effect CIS6 & $0.103(0.039)^{* * *}$ & $0.354(0.055)^{* * *}$ & $-0.046(0.046)$ & $0.053(0.046)$ & $0.034(0.046)$ & $-0.020(0.044)$ \\
\hline Time effect CIS7 & $0.151(0.072)^{* *}$ & $0.261(0.098)^{* * *}$ & $-0.001(0.081)$ & $0.014(0.092)$ & $0.079(0.080)$ & $-0.028(0.080)$ \\
\hline Industry effects & Yes & Yes & Yes & Yes & Yes & Yes \\
\hline \multicolumn{7}{|l|}{ Mundlak terms } \\
\hline R\&D in CIS4 & $0.484(0.079)^{* * *}$ & $0.737(0.121)^{* * *}$ & $0.247(0.088)^{* * *}$ & $0.633(0.108)^{* * *}$ & $0.383(0.086)^{* * *}$ & $0.522(0.093)^{* * *}$ \\
\hline Fin. constr. in CIS4 & $0.095(0.067)$ & $-0.018(0.083)$ & $0.091(0.072)$ & $-0.001(0.074)$ & $0.142(0.074)^{*}$ & $0.098(0.069)$ \\
\hline Turnover (log) (lag), avg. & $0.021(0.044)$ & $0.006(0.071)$ & $-0.020(0.059)$ & $0.016(0.057)$ & $0.038(0.046)$ & $0.056(0.053)$ \\
\hline Market scope, avg. & $0.110(0.055)^{* *}$ & $0.099(0.081)$ & $0.114(0.067)^{*}$ & $0.147(0.067)^{* *}$ & $0.053(0.064)$ & $0.122(0.059)^{* *}$ \\
\hline Human capital (lag), avg. & $0.437(0.192)^{* *}$ & $0.501(0.270)^{*}$ & $0.097(0.216)$ & $0.279(0.225)$ & $0.365(0.217)^{*}$ & $0.468(0.212)^{* *}$ \\
\hline Market share (lag), avg. & $0.037(0.033)$ & $0.042(0.045)$ & $0.055(0.037)$ & $0.056(0.042)$ & $0.016(0.038)$ & $0.045(0.035)$ \\
\hline \multicolumn{7}{|c|}{ Dependent: Financial constraints } \\
\hline Innovation (lag) & $0.052(0.068)$ & $0.201(0.092)^{* *}$ & $-0.038(0.082)$ & $0.141(0.086)$ & $0.106(0.073)$ & $0.018(0.071)$ \\
\hline Fin. constraints (lag) & $0.505(0.069)^{* * *}$ & $0.468(0.074)^{* * *}$ & $0.478(0.075)^{* * *}$ & $0.492(0.073)^{* * *}$ & $0.526(0.066)^{* * *}$ & $0.484(0.065)^{* * *}$ \\
\hline Turnover (log) (lag) & $0.068(0.040)^{*}$ & $0.059(0.040)$ & $0.058(0.041)$ & $0.066(0.041)$ & $0.068(0.040)^{*}$ & $0.069(0.040)^{*}$ \\
\hline Market scope & $0.068(0.051)$ & $0.062(0.050)$ & $0.062(0.051)$ & $0.066(0.051)$ & $0.061(0.050)$ & $0.071(0.051)$ \\
\hline Human capital (lag) & $-0.246(0.134)^{*}$ & $-0.247(0.134)^{*}$ & $-0.245(0.136)^{*}$ & $-0.252(0.137)^{*}$ & $-0.252(0.133)^{*}$ & $-0.239(0.134)^{*}$ \\
\hline Operating margin & $-0.627(0.208)^{* * *}$ & $-0.645(0.209)^{* * *}$ & $-0.615(0.209)^{* * *}$ & $-0.657(0.210)^{* * *}$ & $-0.621(0.208)^{* * *}$ & $-0.650(0.206)^{* * *}$ \\
\hline Age $(\log )$ & $-0.098(0.035)^{* * *}$ & $-0.103(0.036)^{* * *}$ & $-0.110(0.037)^{* * *}$ & $-0.103(0.036)^{* * *}$ & $-0.106(0.034)^{* * *}$ & $-0.104(0.035)^{* * *}$ \\
\hline Group member & $-0.113(0.045)^{* *}$ & $-0.116(0.046)^{* *}$ & $-0.116(0.047)^{* *}$ & $-0.120(0.046)^{* * *}$ & $-0.107(0.044)^{* *}$ & $-0.110(0.046)^{* *}$ \\
\hline Company & $0.061(0.065)$ & $0.072(0.067)$ & $0.072(0.068)$ & $0.050(0.067)$ & $0.060(0.064)$ & $0.057(0.066)$ \\
\hline Foreign ownership & $0.003(0.065)$ & $0.008(0.066)$ & $-0.005(0.067)$ & $-0.001(0.066)$ & $0.003(0.063)$ & $0.000(0.065)$ \\
\hline Time effect CIS6 & $0.545(0.040)^{* * *}$ & $0.560(0.041)^{* * *}$ & $0.551(0.040)^{* * *}$ & $0.555(0.041)^{* * *}$ & $0.543(0.039)^{* * *}$ & $0.542(0.039)^{* * *}$ \\
\hline Time effect CIS7 & $0.380(0.072)^{* * *}$ & $0.387(0.073)^{* * *}$ & $0.384(0.074)^{* * *}$ & $0.381(0.074)^{* * *}$ & $0.372(0.071)^{* * *}$ & $0.378(0.071)^{* * *}$ \\
\hline Industry effects & Yes & Yes & Yes & Yes & Yes & Yes \\
\hline \multicolumn{7}{|l|}{ Mundlak terms } \\
\hline R\&D in CIS4 & $0.083(0.056)$ & $0.017(0.076)$ & $0.029(0.071)$ & $0.070(0.073)$ & $0.032(0.059)$ & $0.082(0.066)$ \\
\hline Fin. constr. in CIS4 & $0.453(0.065)^{* * *}$ & $0.488(0.072)^{* * *}$ & $0.492(0.073)^{* * *}$ & $0.483(0.072)^{* * *}$ & $0.439(0.063)^{* * *}$ & $0.473(0.064)^{* * *}$ \\
\hline Turnover (log) (lag), avg. & $-0.078(0.042)^{*}$ & $-0.067(0.042)$ & $-0.064(0.043)$ & $-0.073(0.043)^{*}$ & $-0.078(0.042)^{*}$ & $-0.075(0.042)^{*}$ \\
\hline Market scope, avg. & $-0.036(0.055)$ & $-0.036(0.055)$ & $-0.019(0.055)$ & $-0.038(0.056)$ & $-0.027(0.054)$ & $-0.033(0.055)$ \\
\hline Human capital (lag), avg. & $0.379(0.182)^{* *}$ & $0.345(0.185)^{*}$ & $0.385(0.187)^{* *}$ & $0.405(0.185)^{* *}$ & $0.395(0.180)^{* *}$ & $0.376(0.182)^{* *}$ \\
\hline Market share (lag), avg. & $0.293(0.276)$ & $0.412(0.281)$ & $0.367(0.281)$ & $0.344(0.281)$ & $0.317(0.271)$ & $0.304(0.276)$ \\
\hline Error correlation i,t & $0.144(0.041)^{* * *}$ & $0.078(0.053)$ & $0.150(0.043)^{* * *}$ & $0.207(0.047)^{* * *}$ & $0.125(0.045)^{* * *}$ & $0.088(0.040)^{* *}$ \\
\hline Error correlation i & $0.460(0.296)$ & $0.135(0.297)$ & $0.145(0.332)$ & $-0.076(0.351)$ & $0.360(0.397)$ & $0.653(0.147)^{* * *}$ \\
\hline SD random effect eq. $A$ & $0.517(0.077)^{* * *}$ & $0.518(0.109)^{* * *}$ & $0.331(0.101)^{* * *}$ & $0.425(0.102)^{* * *}$ & $0.540(0.086)^{* * *}$ & $0.464(0.089)^{* * *}$ \\
\hline SD random effect eq. $B$ & $0.241(0.025)^{* * *}$ & $0.304(0.029)^{* * *}$ & $0.314(0.030)^{* * *}$ & $0.283(0.029) * * *$ & $0.194(0.022)^{* * *}$ & $0.286(0.023)^{* * *}$ \\
\hline Observations & 6973 & 6910 & 6906 & 6982 & 6986 & 6975 \\
\hline Log-Likelihood & -7111 & -5365 & -5918 & -5942 & -6205 & -6371 \\
\hline Wald statistic & 1853 & 1419 & 988 & 1863 & 1449 & 1578 \\
\hline Wald p-value & 0.000 & 0.000 & 0.000 & 0.000 & 0.000 & 0.000 \\
\hline
\end{tabular}

Notes: This table presents results for bivariate panel probit models with six innovation measures and a financial constraints measure as dependent variables. All models are estimated using maximum simulated likelihood with 100 random draws and standard errors (in parentheses) based on the outer product of the matrix of contributions to the gradient. Intercepts and industry effects are not shown. All specifications in this table use Mundlak (1978) time averages rather than Wooldridge terms for the random effect's conditional mean. Significance levels: $* * * \mathrm{p}<0.01,{ }^{* *} \mathrm{p}<0.05, * \mathrm{p}<0.1$. 